\title{
DERECHOS HUMANOS EN LA JURISPRUDENCIA DEL TRIBUNAL CONSTITUCIONAL CHILENO. APOSTILLAS SOBRE TRATADOS Y CONSTITUCIÓN*
}

\author{
POR \\ FRANCISCO ZÚNIIGA URBINA \\ Profesor de Derecho Constitucional \\ Universidad de Chile
}

\section{PROLEGÓMENOS}

La reforma constitucional de 1989 promulgada mediante Ley n. ${ }^{\circ} 18.825$, conocida como las " 54 reformas» inicia un ciclo de transición (consecuencia del malogrado plebiscito de continuidad del régimen y del autócrata de 5 de octubre de 1988) y depuración de una Constitución otorgada, autoritaria y neoliberal en sus «enclaves autoritarios», que se cierra recién después 17 enmiendas el año 2005 con la reforma promulgada mediante la Ley n. ${ }^{\circ} 20.050$, y la fijación (necesaria, "cosmética» o "estética» se dirá) de un nuevo texto refundido, coordinado y sis-

* Ponencia a XXXVII Jornadas Chilenas de Derecho Público, Pontificia Universidad Católica de Valparaíso, Comisión de Derecho Constitucional, 8 y 9 de noviembre de 2007. La ponencia tiene su origen en una intervención realizada en el Seminario «La Aplicación del Derecho Internacional de los Derechos Humanos en el Derecho Interno", que se publicará en Estudios Constitucionales del segundo semestre de 2007. Sin embargo, la ponencia ameritó una viva polémica con profesores extranjeros y nacionales, por lo que me atrevo a revisitar el tema a través de estas Apostillas. 
tematizado de la Constitución Política de la República a través del Decreto Supremo (DS) n. ${ }^{\circ}$ 100, de Segpres, de 2005. La fútil o artificiosa discusión acerca de si la Constitución vigente hoy es nueva o vieja Carta, nos lleva a afirmar que se trata de Constitución «vieja-nueva» o Constitución de «1980-2005», vieja por conservar en lo grueso una Constitución Económica y Constitución Social de orientación neoliberal-conservadora (iusnaturalista), y nueva por la depuración de sus enclaves autoritarios, al precio de conservar el binominalismo como fórmula electoral parlamentaria a través de una legislación orgánica reforzada en su quórum.

A los efectos de nuestra exposición, nos interesa referirnos a la primera reforma de 1989, específicamente la adición al artículo $5 .^{\circ}$ inciso segundo de la Constitución de una garantía institucional genérica, que impone deberes al Estado: deber de respeto (negativo-positivo) y deber promoción (positivo) de derechos fundamentales y derechos humanos reconocidos en tratados internacionales ratificados y vigentes. Esta enmienda generó una larga y concurrida disputa entre internacionalistas y constitucionalistas, acerca de sus alcances y especialmente el desenfocado tema de la jerarquía de los tratados de derechos humanos.

Una lectura de dicha reforma constitucional acerca del artículo $5 .^{\circ}$ inciso segundo de la Constitución la hace un protagonista de época de ésta el profesor Francisco Cumplido: «La Constitución de 1980 reforzó el carácter de los derechos humanos en el sistema constitucional chileno. En efecto, el inciso segundo del artículo $5 .^{\circ}$ establece, nada menos, que el ejercicio de la soberanía reconoce como limitación al respecto a los derechos esenciales que emanan de la naturaleza humana. Coloca pues sobre la soberanía a tales derechos. Por su parte, el artículo $1 .^{\circ}$ prescribe que las personas nacen libres e iguales en dignidad y derecho, afirmación contenida en varias convenciones sobre derechos humanos. Agrega que el Estado está al servicio de la persona humana. En la historia fidedigna de esta disposición constitucional quedó expresa constancia que la protección constitucional se refiere no sólo a los derechos establecidos en ella, sino a todos los que son inherentes a la naturaleza humana, como asimismo se reconoció que tales derechos no sólo son los enumerados en el texto de la Constitución, en los capítulos segundo y tercero, sino también los que formen parte del acervo cultural de la humanidad y que son propios de la naturaleza humana (Actas de la Comisión de la Nueva Constitución, sesión 203). ¿Por qué resolvimos, entonces, aceptar incorporar expresamente, a lo menos, los derechos contenidos en los tratados internacionales ratificados por Chile y que se encuentren vigentes? «En primer término, porque sólo esporádicamente los tribunales aplicaban directamente las normas de la Constitución y, también, frecuentemente, exigían que la legislación recepcionara lo convenido en los tratados internacionales». «En segundo término, se había producido durante el gobierno militar la suscripción, ratificación y pro- 
mulgación de tratados sobre derechos humanos y, al no ser publicados en el Diario Oficial, los tribunales no los aplicaban por estimar que no estaban vigentes. Así ocurrió con el Pacto de Derechos Civiles y Políticos promulgado en 1976, y publicado sólo en el mes de abril de 1989, con el Pacto Internacional de Derechos Económicos y Sociales, ratificado en 1976 y promulgado y publicado el 27 de mayo de 1989, con la Convención Americana sobre Derechos Humanos —Pacto de San José de Costa Rica—, sólo publicada en 1991». «Los que negociamos la reforma entendimos que con la frase agregada por ella se lograba que los derechos garantizados por la Constitución y por los tratados ratificados y vigentes, tuvieran la misma jerarquía en el ordenamiento jurídico. En este sentido incorporábamos los derechos asegurados por los tratados a la Constitución» (...) «En segundo término les dábamos a los referidos tratados al carácter de vinculantes para todos los órganos del Estado, ya que debían no sólo respetarlos, sino que también promoverlos. Lo incorporado a la Constitución son los derechos sustantivos, no la parte adjetiva del tratado».(...) «El enunciado de los derechos esenciales de la persona humana asegurados por la Constitución de 1980 no es taxativo, es decir, no sólo son tales los regulados por la Constitución y por los tratados internacionales ratificados por Chile y vigentes, sino todos los que sean necesarios para proteger la dignidad humana, teniendo en cuenta lo dispuesto por el artículo 1 , incisos 1 y 4 , artículo $5 .^{\circ}$ inciso $2 .^{\circ}$, ambos Bases de la Institucionalidad, y el artículo 19 inciso 1 y n. ${ }^{\circ} 26 »$. Por ello fue un lugar común en parte de la doctrina constitucionalista e internacionalista (Medina) sostener que la reforma comentada modificaba la jerarquía normativa de los tratados referentes a derechos humanos o más precisamente "derechos esenciales», lo que extiende esta jerarquía iusfundamental a todos los tratados que contengan alguna disposición relativa a la protección de derechos ${ }^{1}$.

Han transcurrido más de tres lustros y existen algunos consensos básicos en nuestra disciplina constitucionalista, como «tomarnos en serio» los tratados in-

${ }^{1}$ Esta relación del profesor Francisco Cumplido está tomada de su trabajo «La reforma constitucional de $1989 \mathrm{al}$ inciso $2 .^{\circ}$ del artículo $5 .^{\circ}$ de la Constitución: sentido y alcance de la reforma. Doctrina y jurisprudencia» en Seminario Internacional sobre Derechos Humanos, Constitución y Tratados Internacionales, organizado por la Facultad de Derecho de la Universidad de Talca, en mayo de 2003, Revista Ius et Praxis n. ${ }^{\circ}$ 1, año 9, 2003, pp. 365-374, en especial págs. 369-370. Del mismo autor "Alcances de la modificación al artículo 5. ${ }^{\circ}$ de la Constitución», en Revista Chilena de Derecho, vol. 23 n. 2 y 3, Facultad de Derecho, Pontificia Universidad Católica de Chile, Santiago, 1996. De la profesora Cecilia Medina Quiroga su estudio «El Derecho Internacional de los Derechos Humanos y el Ordenamiento Jurídico Chileno» en el libro «Constitución, Tratados y Derechos Esenciales» Editado por la Corporación Nacional de Reparación y Reconcialiación, Santiago, 1994, en especial págs. 48-49. 
ternacionales, de lo que da cuenta la nueva regla de incorporación o recepción de tratados del artículo $32 \mathrm{n} .^{\circ} 15$ y artículo 54 n. ${ }^{\circ} 1$, y el equilibrio Gobierno Congreso Nacional, puesto que la cláusula del primitivo artículo $50 \mathrm{n} .^{\circ} 1$ resultaba anacrónica. Con todo nuestra Constitución sigue siendo en gran parte «insular».

El debate hoy no pasa por la supuesta jerarquía de los tratados internacionales en el Derecho interno (jerarquía supra, infra o constitucional) o la apertura de un procedimiento secundario de reforma constitucional y una materialidad iusfundamental de tratados de derechos humanos, como sostuvo con vehemencia y pertinacia el profesor Nogueira Alcalá en nuestro medio, ideas abandonadas hoy en parte por este autor; sino por la recepción de una categoría dogmática como el «bloque constitucional» o «bloque de constitucionalidad» de clara filiación en el Derecho Comparado, y que bajo la fórmula de «bloque constitucional de derechos», repone en la Constitución material los tratados de derechos humanos o más precisamente las normas de tratados sobre derechos humanos ${ }^{2}$.

De este modo, el «bloque constitucional de derechos» se transforma en la herramienta dogmática para conferir materialidad iusfundamental a los tratados de derechos humanos y para conferir una seudo-forma iusfundamental a éstos al introducir en el parámetro o derecho material del control de constitucionalidad de la ley y actos estatales encomendado al Tribunal Constitucional, estas normas seudo iusfundamentales.

En otro lugar hemos examinado la inadecuación de la categoría de «bloque de constitucionalidad" para conferir materialidad a los tratados internacionales de derechos humanos ratificados y vigentes, a la luz del artículo $5 .^{\circ}$ inciso segundo de la Constitución, por lo que en esta ponencia nos proponemos examinar la doctrina jurisprudencial del Tribunal Constitucional en relación al mentado artículo $5 .^{\circ}$ inciso segundo, especialmente a través de dos sentencias: la de control abstracto y contencioso de constitucionalidad del Tratado que fija el Estatuto de Roma de la Corte Penal Internacional de 2002 y la de control abstracto y contencioso con motivo de la impugnación del proyecto de ley de responsabilidad adolescente de 2007; y en dos momentos: un «antes» y un «después» en base a la reforma constitucional de 2005 que instaló una nueva o refundada Judicatura ${ }^{3}$.

${ }^{2}$ Nogueira Alcalá, Humberto: «Lineamientos de interpretación constitucional y del bloque constitucional de derechos», Librotecnia, Santiago, 2006. También consultar un panorama general en la obra de Victor Bazán: "Jurisdicción Constitucional y control de constitucionalidad de los tratados internacionales. Un análisis de derecho comparado», Porrúa, México D.F. 2003.

3 Zúñiga Urbina, Francisco: "Control de Constitucionalidad y Sentencia», Edit. Tribunal Constitucional, Santiago, 2006. 


\section{DOCTRINA DEL TRIBUNAL CONSTITUCIONAL}

En la jurisprudencia del Tribunal Constitucional en materia de derechos humanos y artículo $5 .^{\circ}$ inciso segundo de la Constitución el «antes» de esta Judicatura está dado por dos sentencias de cita obligada: la relativa al caso de Clodomiro Almeyda Medina (Rol n. ${ }^{\circ} 46$, de 1987) anterior a la reforma constitucional de 1989, que hemos tenido la oportunidad de comentar en otro lugar y la relativa al Tratado que fija el Estatuto de Roma de la Corte Penal Internacional (Rol n. ${ }^{\circ}$ 346, de 2002) posterior a la reforma constitucional de 1989.

En la sentencia del caso Almeyda el Tribunal Constitucional consigna, a partir de una estructura argumentativa muy elemental, la conclusión siguiente: «Que la prevalencia en el orden interno de los preceptos constitucionales sobre las disposiciones de un tratado resulta, por lo demás, del todo consecuente con el sistema jurídico, ya que la interpretación contraria significa permitir la reforma de la Carta Fundamental por un modo distinto del establecido en sus artículos 116 a 118. De allí que dicha prevalencia, tanto en la doctrina nacional como extranjera, sea la generalmente aceptada, salvo en aquellos casos excepcionalísimos en que la propia preceptiva constitucional respectiva establezca lo contrario» (cons. $28 .{ }^{\circ}$ ).

En la sentencia del Tribunal Constitucional Rol n. 346 de 2002, recaída en la constitucionalidad del Tratado que fija el Estatuto de Roma de la Corte Penal Internacional, esta Magistratura estableció una estructura argumentativa o ratio decidendi que da cuenta, sin decirlo dada la precariedad dogmática del fallo, de la falta de una regla de habilitación en materia de tratados que permita la transferencia o delegación de potestades soberanas, que entre otros aspectos consigna:

36. ${ }^{\circ}$ Que, la disposición transcrita tiene su origen en la Constitución de 1925, que en su artículo 2. ${ }^{\circ}$ decía: "La soberanía reside en la Nación, la cual delega su ejercicio en las autoridades que esta Constitución establece»;

37. Que, la Constitución de 1980 al establecer el principio de la soberanía nacional, ha aclarado sustancialmente el concepto en relación a la Constitución anterior, por las siguientes razones: a) Porque hizo una clara distinción entre el titular de la soberanía y quien la ejerce (Comisión de Estudio de la Nueva Constitución, Sesiones n. ${ }^{\text {os }} 413$ y siguientes). El titular es la Nación y su ejercicio corresponde al pueblo que la realiza a través del plebiscito y de elecciones periódicas y corresponde además a las autoridades que la propia Constitución establece. Cabe destacar que el Constituyente utilizó el vocablo «esta Constitución» al referirse a la posibilidad que las autoridades ejerzan soberanía de lo que se desprende con claridad que sólo éstas, además del pueblo, son las únicas que pueden ejercerla válidamente. b) Se diferencia también la Constitución actual de la Constitución de 1925, porque establece expresamente un límite al ejercicio de la sobe- 
ranía, cual es, el respeto a los derechos esenciales que emanan de la naturaleza humana. Adopta así el texto actual una concepción que significa que la gran garantía de los derechos es la Constitución, pues establece expresamente un límite al ejercicio de la soberanía;

38. Que, la soberanía se ha entendido como el Poder del Estado, o en forma más precisa, como una cualidad de dicho Poder: no admite a otro ni por encima de él ni en concurrencia con él;

39. Que, el concepto de soberanía ha evolucionado con los tiempos de manera que hoy se reconoce que limitan su ejercicio los derechos esenciales que emanan de la naturaleza humana, como lo dice expresamente nuestra Carta Fundamental;

40. Que, el Constituyente ha sido claro al referirse a la soberanía. Ha señalado con precisión quién es su titular — la Nación, o sea, aquella agrupación de personas, unidas por vínculos materiales y espirituales, que los hace tener conciencia de poseer caracteres comunes que les permite diferenciarse de otros grupos nacionales, y en que los individuos manifiestan y demuestran tener la voluntad de conservar esos lazos de unidad. Se comprenden en este concepto, las generaciones pasadas, presentes y futuras. Ha indicado, también, quien ejercita la soberanía: el pueblo y las autoridades que la Constitución establece y ha adoptado una posición acorde con los tiempos actuales, al señalar que cuando se ejercita existe un límite que es el respeto a los derechos esenciales que emanan de la naturaleza humana;

41. Que, las únicas autoridades que pueden ejercitar soberanía son las que la Constitución establece, entre las que destaca el Presidente de la República, el Congreso Nacional y los Tribunales de la Nación. Las funciones y atribuciones que la Constitución entrega a estas autoridades constituyen la forma en que la soberanía se manifiesta y se hace realidad;

53. Que, si bien el concepto de soberanía ha evolucionado y no es absoluto como se le concibió en el siglo XVIII, y prueba de ello es que la propia Constitución le ha señalado un límite - los derechos esenciales que emanan de la naturaleza humana-, no es dable pretender que las funciones por las que se manifiesta el Poder del Estado puedan ser renunciadas, ya sea a través de una delegación o cesión no autorizada por el Constituyente;

56. Que, desde otra perspectiva, el Presidente de la República, en su respuesta, ha entrado a distinguir entre jurisdicción interna y jurisdicción externa o internacional de los tribunales chilenos, sosteniendo que la prohibición de delegar la soberanía jurisdiccional sólo alcanza a la primera. Si bien es lícito hacer la distinción, toda vez que nuestro ordenamiento permite a los órganos nacionales extender su ámbito jurisdiccional a conflictos ocurridos fuera de la República, el doble alcance que puede tener dicha función soberana no permite concluir que sólo respecto de la interna se encuentra vedada su delegación. La jurisdicción es una, única y —salvo para fines meramente didácticos-, conceptualmente indivisible, de manera que el distingo propuesto, a más de artificioso, no permite arri- 
bar a la conclusión que una sea delegable y la otra no lo sea. No se divisa otra forma de permitir la propuesta delegación, que una específica reforma constitucional;

58. ${ }^{\circ}$ Que, en síntesis, el incorporar a un tribunal de justicia con competencia para resolver conflictos actualmente sometidos a la jurisdicción chilena, e incluirlo entre las autoridades que esta constitución "establece», en concordancia con el artículo 74, ya citado, debe necesariamente ser autorizado por el Constituyente. En consecuencia, para que la Corte Penal Internacional sea un tribunal establecido para juzgar delitos cometidos en Chile, debe incorporarse al sistema interno mediante una adecuación constitucional»;

La larga cita fragmentaria del fallo recoge un componente de la estructura argumentativa de la sentencia del Tribunal Constitucional, que deja en evidencia una visión tradicional del Estado y del principio-dogma de la soberanía (supremacía, unidad, indivisibilidad, perpetuidad, etc.), pero con anclaje iusfundamental en el artículo $5 .^{\circ}$ inciso primero de la Constitución; de suerte que no es admisible una transferencia o cesión de potestades soberanas en el marco de un tratado solemne multilateral (funciones investigativa y jurisdiccional unidas al poder punitivo del Estado); todo lo cual deja en evidencia de un modo un tanto implícito que nuestra Constitución sólo posee una regla de incorporación de derecho de los tratados al Derecho interno y no una regla de habilitación, que permita hacer el distingo entre soberanía interna y externa para los efectos de una transferencia o delegación de potestades soberanas. Subyace, nuevamente de un modo un tanto implícito, a la estructura argumentativa de la sentencia del Tribunal Constitucional la definición de la Constitución como sistema de reglas de competencias, de suerte que sólo una regla de habilitación acerca de tratados internacionales podría admitir la transferencia o delegación de potestades soberanas o "derechos de soberanía» (Hocheitsrechte) como los denomina la doctrina germana ${ }^{4}$.

${ }^{4}$ Nogueira Alcalá, Humberto: «Consideraciones sobre el fallo del Tribunal Constitucional de Chile respecto del Tratado de Roma y establece la Corte Penal Internacional», en Anuario de Derecho Constitucional Latinoamericano, 2002, pp. 449-466. Sobre la distinción entre la regla de incorporación o recepción, que hace posible un procedimiento especial de adaptación o recepción de tratados, y la regla de habilitación que permite transferir o delegar en una instancia supranacional la competencia para producir Derecho, «...Derecho que a continuación, sin ninguna mediación estatal ulterior, va a tener vigencia como Derecho interno", la tomamos de las funciones asignadas a la aprobación de tratado en el derecho nacional por juristas como Javier Pérez Royo y Klaus Stern. Consultar de Pérez Royo los análisis de los artículos 93, 94 y 95.1 de la Constitución española en «Las Fuentes del Derecho», Tecnos, 1 edic. 1984, 4. ${ }^{a}$ edic. de 1988, 2. ${ }^{a}$ reimpresión, Madrid, 1991, pp. 146-147, y también en su magnífico "Curso de Derecho Constitucional», Marcial Pons, 6. a edic., Madrid, Barcelona, 1999, pp. 800-804,pp. 1057-1081. De K. Stern el análisis de los artículos 24 y 59.2.1 de la Ley Fundamental en su obra «Derecho del Estado en la República Federal Alemana» (trad. J. Pérez Royo y P. Cruz Villalón), CEC, Madrid, 1987, pp. 844-848, y pp. 869-871. 
Luego, para el Tribunal Constitucional la incorporación del Tratado que fija el Estatuto de Roma de la Corte Penal Internacional requiere de una reforma constitucional. Por ello, está pendiente de trámite en el Senado una reforma a la Constitución, que por la vía de una "Disposición Transitoria» admite la habilitación y transferencia de potestades soberanas.

Con todo, más allá de la precariedad dogmática de la sentencia comentada y no siendo este el lugar para abordar esta cuestión, es menester consignar lo dudoso que resulta atribuir, como lo hace la sentencia del Tribunal Constitucional, al Tratado que fija el Estatuto de Roma de la Corte Penal Internacional, el carácter de tratado solemne y multilateral que importa transferencia de potestades soberanas, a la luz de la mentada regla de complementariedad que este instrumento reconoce y desarrolla en su preceptiva.

En otro orden de materias, el Tribunal Constitucional consigna en este fallo un verdadero obiter dicta, en un apartado titulado «VI. La jerarquía de los tratados.», en el cual define el locus de los tratados de derechos humanos en el Derecho interno. La sentencia incluye para el obiter dicta los fundamentos jurídicos siguientes sobre esta materia:

59. ${ }^{\circ}$ Que, por la reforma constitucional de 1989, se modificó el artículo $5^{\circ}$ de la Constitución Política, agregando un inciso segundo. Esta disposición dice: "El ejercicio de la soberanía reconoce como limitación el respeto a los derechos esenciales que emanan de la naturaleza humana. Es deber de los órganos del Estado respetar y promover tales derechos, garantizados por esta Constitución, asi como por los tratados internacionales ratificados por Chile y que se encuentren vigentes";

$60 .^{\circ}$ Que, como consecuencia de esta reforma se ha suscitado una controversia respecto a la interpretación que debe darse al inciso segundo del artículo $5^{\circ}$, de la Constitución. La nueva redacción ha llevado a algunos a pretender que los tratados sobre derechos humanos tendrían rango constitucional, de manera que podrían modificar disposiciones de la Carta Fundamental. Dada la estrecha relación entre este tema y el que se analiza en esta causa, se hace necesario dilucidar esta controversia, máxime cuando en la fundamentación de las observaciones formuladas por el Presidente de la República subyace la idea que el derecho internacional convencional sobre derechos humanos prevalece sobre la Constitución;

61. Que, con anterioridad a la reforma de 1989, había opinión unánime en el sentido que los tratados internacionales estaban sujetos al principio de supremacía constitucional;

62. Que, en este aspecto, es relevante recordar que, aunque aparezca obvio, la norma constitucional reformada no consagró que los tratados internacionales sobre derechos esenciales tuvieran una jerarquía igual o superior a la Ley Fundamental;

63..$^{\circ}$ Que, la historia fidedigna de la norma corrobora el aserto anterior. En el Informe de la Comisión Conjunta de la Junta de Gobierno, de 12 de junio 
de 1989, se dejó expresa constancia que: «En virtud de este número se agrega una oración final al inciso segundo del artículo $5 .^{\circ}$ de la Constitución, que dice: «Es deber de los órganos del Estado respetar y promover tales derechos, garantizados por esta Constitución, así como por los tratados internacionales ratificados por Chile y que se encuentran vigentes. Esta disposición reafirma el concepto de que el Estado está al servicio de la persona humana y que, por tanto, el ejercicio de la soberanía no puede vulnerar los derechos esenciales que emanan de su naturaleza. A la autoridad le corresponde, también, la promoción de los derechos humanos, los que, emanando de la naturaleza de la persona, no son establecidos por la Constitución, sino que ésta se limita a reconocerlos y a describirlos, pudiendo las leyes y los tratados desarrollarlos sin afectar su esencia.

En relación con los tratados a que se refiere esta norma, cabe señalar que su vigencia no obsta a la procedencia del recurso de inaplicabilidad por inconstitucionalidad conforme a las reglas generales.» Lo anterior nos permite afirmar que no estuvo en la mente del Constituyente que los tratados no quedaran sujetos a la supremacía de la Constitución ni menos que su jerarquía permitiera enmendar normas de la Ley Fundamental, ya que si así no fuere carece de toda explicación lógica y jurídica que se hubiere afirmado que era procedente el recurso de inaplicabilidad de una norma de un tratado por ser contraria a la Constitución, habida consideración que dicho recurso reconoce como causa inmediata, precisamente, la prevalencia de la Constitución sobre la ley o el tratado. Comentando este Informe, el profesor Raúl Bertelsen, en su trabajo «Rango Jurídico de los Tratados Internacionales en el Derecho Chileno» (Revista Chilena de Derecho, Vol. 23, n. ${ }^{\text {os }} 2$ y 3, Tomo I, pág. 219), dice: «¿Cabe, entonces, alguna duda que las normas de los tratados internacionales sobre derechos humanos están subordinadas a la Constitución si pueden ser contrastadas con los preceptos de ésta para ser declaradas inaplicables? Nada se innovó en 1989, por consiguiente, en la solución tradicional chilena sobre la superioridad de las normas constitucionales sobre las de los tratados internacionales»;

64. ${ }^{\circ}$ Que, con anterioridad a la reforma de 1989 este Tribunal, en sentencia de 21 de diciembre de 1987, Rol n. ${ }^{\circ}$ 46, señaló expresamente que las normas constitucionales, en el orden interno, prevalecen sobre las disposiciones contenidas en tratados internacionales;

65. Que, este criterio fue confirmado en acuerdo de la Comisión de Constitución, Legislación, Justicia y Reglamento del Senado, sobre Reforma a la Constitución Política de la República de 1980, de noviembre de 2001, en el que se hizo expresa mención al contenido del Rol n. ${ }^{\circ} 46$, antes citado, y expresó: «En relación a la propuesta referida a tratados que modifiquen materias reguladas por la Constitución, se acordó, sin embargo, dejar constancia que la Comisión confirma el criterio ya definido en un informe evacuado en el año 1963, en el cual, respondiendo a una consulta de la Sala (Boletín n. ${ }^{\circ}$ S 139-10), señaló, coincidiendo con lo sostenido por el Tribunal Constitucional en sentencia de fecha 21 
de diciembre de 1987, que no procede enmendar la Constitución por la vía de un tratado internacional» (págs. 349 y 350);

66. Que, para la interpretación de la reforma constitucional en análisis, tiene gran importancia esta afirmación de la Comisión, pues para determinar el sentido del artículo $5^{\circ}$, inciso segundo, utiliza el mismo criterio de un informe del año 1963, y deja constancia, en esta forma, que la Constitución prevalece sobre los tratados que se refieran a derechos humanos;

67. Que, con posterioridad a la reforma de 1989, este propio Tribunal en sentencia de 4 de agosto del año 2000, Rol n. ${ }^{\circ}$ 309, señaló que «si un tratado internacional contiene normas propias de ley orgánica constitucional, el acuerdo del Congreso para su aprobación o rechazo exige el quórum establecido por la Constitución para esa clase de leyes» (considerando 17. ${ }^{\circ}$ ). Si las distintas materias del tratado deben respetar los quórums de aprobación o rechazo que indica el artículo 63 de la Constitución Política, resulta que es indudable la absoluta sujeción de los tratados internacionales a la Carta Política;

68. Que, sobre el particular, el profesor Lautaro Ríos, señala: «Ninguna constitución contempla el logro automático de la jerarquía constitucional mediante un simple proceso semántico como el que se pretende hacer con la oración agregada al inc. $2 .^{\circ}$ del art. $5 .^{\circ}$ de nuestra Carta, que tiene — manifiestamenteotro alcance, como ya vimos. La desmesurada pretensión de identificar el rango de los tratados internacionales sobre DD. HH. con la suprema jerarquía normativa de la Constitución, choca abruptamente con el sistema mixto de control de constitucionalidad de la ley, tanto preventivo como represivo, entregados al Tribunal Constitucional y a la Corte Suprema, según el caso, los que no serían operables si los tratados sobre DD.HH. tuvieran rango constitucional per se. Dicha pretensión también atenta contra el delicado mecanismo de reforma de la Carta Fundamental, contenido en un capítulo especial, el Capítulo XIV, y que se caracteriza por su notable rigidez, especialmente tratándose de la reforma del capítulo relativo a los derechos y deberes constitucionales, cuya estabilidad y preservación el constituyente aseguró exigiendo un quórum reforzado de las dos terceras partes de los diputados y senadores en ejercicio. Tanto este quórum especial como los trámites propios de una ley y de reforma quedarían reemplazados por el quórum y los trámites de una ley ordinaria que, además, tendría el efecto de reformar la Constitución si aceptáramos el rango constitucional de los tratados sobre DD.HH. y su eventual carácter modificatorio de la Constitución. Una interpretación semejante, para ser armónica con el resto de la preceptiva constitucional, debiera haberse plasmado en un texto diferente debiera haber venido acompañada de la modificación de los arts. 80, 82, n. ${ }^{\circ}$ 2, y del Capítulo XIV de a Constitución.» ("Jerarquía Normativa de los Tratados Internacionales sobre Derechos Humanos», en Gaceta Jurídica n. 215, 1998, pág. 13);

69. Que, sostener que los tratados internacionales sobre derechos humanos puedan modificar la Constitución, conduce a que pierdan eficacia las disposi- 
ciones que permiten el control previo de constitucionalidad de los tratados (artículo 82, n. ${ }^{\circ}$, de la Constitución) y el 2 control a posteriori (artículo 80, de la Constitución) ¿pues qué sentido tendrían estos controles si las normas del tratado sobre derechos humanos tuvieren el mismo rango jerárquico que la Constitución?;

70. ${ }^{\circ}$ Que, igualmente quedaría sin sentido, parcialmente, el Capítulo XIV de la Ley Fundamental sobre Reforma de la Constitución, si por la vía de los tratados internacionales sobre derechos humanos se pudiera enmendar su texto. Llegaríamos al absurdo que mediante el quórum simple podría modificarse la Carta Política que exige el quórum de tres quintos o de dos tercios de los miembros en ejercicio de cada Cámara, según sea la materia que se reforma;

71. ${ }^{\circ}$ Que, el sentido que debe darse a la frase agregada al artículo $5 .^{\circ}$ de la Constitución, es que el Constituyente quiere dar énfasis a las derechos fundamentales, señalando que es deber para los órganos del Estado, respetarlos y promoverlos, no sólo los derechos asegurados en la Constitución, sino que también los contenidos en tratados internacionales ratificados por Chile y que se encuentren vigentes;

72. ${ }^{\circ}$ Que, si aplicamos el criterio de interpretación de unidad y coherencia del texto constitucional, es evidente que el artículo $5 .^{\circ}$, inciso segundo, de la Ley Fundamental, no puede analizarse aisladamente y debe armonizarse con las siguientes disposiciones constitucionales, lo que nos lleva a hacer primar las normas fundamentales sobre las de los tratados internacionales sobre derechos humanos vigentes y ratificados por Chile»;

El Tribunal Constitucional empleando la técnica del obiter dicta, que ameritó la prevención del Ministro Juan Agustín Figueroa Y. en orden a que dicha materia era ajena «a la situación sub-lite, por lo que no resulta útil todo aquel desarrollo argumental», señala que la supremacía constitucional en relación a los tratados es incuestionable en la medida que se someten al control de constitucionalidad preventivo de esta Magistratura y al control de constitucionalidad represivo de la Corte Suprema en virtud del hoy derogado artículo 80, y su posición infraconstitucional queda reforzada por su inserción en el Derecho interno con sujeción a la normas iusfundamentales acerca de competencia legislativa y tipos de ley (en especial quórum de legislación), así como la determinación de un procedimiento de reforma constitucional; con lo cual se reitera doctrina jurisprudencial anterior recogida en las sentencias Rol n. 46 de 1987 (anterior a la reforma de 1989) y Rol n. ${ }^{\circ} 309$ de 2000 . Cita al efecto el Tribunal Constitucional en la sentencia comentada una parte de la doctrina nacional en la materia.

El Tribunal Constitucional, sin ser explícito en el obiter dicta retoma la definición de la Constitución como sistema de reglas de competencias, de suerte que las competencias normativas y su jerarquía sólo pueden tener su fuente en 
Carta, criterio con el cual concordamos. En palabras de Vanossi y Dalla Via : «Si la Constitución es la norma que formula el reparto de competencias o atribuciones entre los poderes del Estado y, a la vez, dispone el orden de prelación de las normas, partiendo de su rigidez como tal, resulta que únicamente por medio de una reforma constitucional se puede cambiar ese orden de primacía de normas y asegurar a través de su consiguiente rigidez una nueva distribución de competencias. Si las Constituciones rígidas limitan o impiden la delegación interna de poderes, no es coherente sostener la validez de una delegación de atribuciones del estado en órganos supranacionales invocando alardes hermenéuticos. Hace falta, en esos casos, una reforma constitucional que consagre normativamente la decisión política fundamental de integrar el estado en un ordenamiento donde se delegan atribuciones inherentes a la soberanía clásica ${ }^{5}$.

\section{DOCTRINA DEL NUEVO TRIBUNAL CONSTITUCIONAL}

El nuevo o refundado Tribunal Constitucional en la sentencia Rol n. ${ }^{\circ} 786$ de 2007, vino de vueltas al tema que sirve de base a esta exposición, con motivo del contencioso originado a raíz de la impugnación de la norma adicionada en el artículo $23 \mathrm{n} .{ }^{\circ} 1$ al proyecto de ley que modifica la Ley $n .{ }^{\circ} 20.084$ que establece un sistema de responsabilidad adolescente por infracción a la ley penal, relativo al locus de los tratados de derechos humanos en el Derecho interno y a su eficacia normativa, eludiendo una definición en el tema, consignando en su estructura argumentativa o ratio decidendi los fundamentos siguientes:

QUINTO: Que el conflicto jurídico sometido a la decisión de esta Magistratura consiste en el examen abstracto del precepto impugnado del proyecto de ley modificatorio de la Ley $\mathrm{N}^{\circ} 20.084$ en relación con su conformidad o disconformidad con la Carta Fundamental. Así, el examen se ha de realizar mediante el cotejo objetivo entre el precepto infraconstitucional que se impugna con los valores, principios y normas consagrados en la Carta Fundamental. Por ende, este tipo de control no tiene por objeto directo el amparo o tutela de derechos fundamentales, pues no es de tal naturaleza la acción deducida;

VIGESIMOQUINTO: Que, habiéndose rechazado las inconstitucionalidades de forma alegadas en el requerimiento, corresponde pronunciarse sobre el vicio de fondo invocado y que consiste en que el artículo $23 \mathrm{n} .{ }^{\circ} 1$, contenido en el numeral 3 del artículo único del proyecto de ley modificatorio de la Ley n. $^{\circ}$

5 Vanossi, Jorge Reinaldo y Dalla Via, Alberto Ricardo: «Régimen Constitucional de los Tratados» (prólogos de S. V. Linares Quintana y G.J. Bidart Campos) Edit. Abeledo Perrot, 2. edic., Buenos Aires, 2000, en especial pág. 25. 
20.084, sobre responsabilidad de los adolescentes por infracciones a la ley penal, vulneraría el artículo 5. ${ }^{\circ}$, inciso segundo, de la Carta Fundamental en relación con los artículos 3.1, 37, 40 y 41 de la Convención sobre los Derechos del Niño y con el principio de no retroceso en materia de derechos humanos;

VIGESIMOSEXTO: Que la referida inconstitucionalidad consistiría, específicamente, a juicio de los requirentes, en que al establecer la norma impugnada del proyecto modificatorio de la Ley n. ${ }^{\circ} 20.084$, como única sanción posible, para el tramo de penalidad superior a 5 años, la de internación en régimen cerrado, configuraría una violación al artículo $5 .^{\circ}$, inciso segundo, de la Carta Fundamental que consagra el deber de los órganos del Estado — como es el caso del legislador - de respetar y promover los derechos esenciales del ser humano garantizados por la Constitución y los tratados internacionales ratificados por Chile y que se encuentren vigentes. Ello, porque el legislador no habría respetado el principio del interés superior del niño, consagrado en el artículo 3.1 de la Convención sobre los Derechos del Niño, así como los artículos 37, 40 y 41 de la misma, según los cuales la privación de libertad de los adolescentes debe ser la ultima ratio e imponerse por el menor tiempo posible;

VIGESIMOSÉPTIMO: Que planteada, en esos términos, la cuestión de constitucionalidad sometida a la decisión de este Tribunal, ella debe ser necesariamente desechada, por las razones que se expresarán.

Cabe destacar, en tal sentido, que todo el sistema de responsabilidad penal del adolescente, en nuestro país, está basado en la necesidad del respeto a sus derechos y, en particular, del «interés superior» del mismo. Ello se comprueba al examinar en detalle la normativa contenida en la Ley n. 20.084 y, específicamente, su artículo $2 .^{\circ}$, que establece:

"Interés superior del adolescente. En todas las actuaciones judiciales o administrativas relativas a los procedimientos, sanciones y medidas aplicables a los adolescentes infractores de la ley penal, se deberá tener en consideración el interés superior del adolescente, que se expresa en el reconocimiento y respeto de sus derechos".

«En la aplicación de la presente ley, las autoridades tendrán en consideración todos los derechos y garantías que les son reconocidos en la Constitución, en las leyes, en la Convención sobre los Derechos del Niño y en los demás instrumentos internacionales ratificados por Chile y que se encuentren vigentes».

La norma transcrita no fue modificada por el proyecto de ley que se impugna, originado en el Mensaje Presidencial n. ${ }^{\circ}$ 170-355 y complementado, entre otras, por la indicación impugnada en este proceso. En el texto del Mensaje se lee precisamente que: «... con la implementación de una nueva justicia penal adolescente ... se pretende, además de dar cumplimiento a numerosos y diversos tratados internacionales en materia de infancia y adolescencia ...";

VIGESIMOCTAVO: Que, en ese contexto, no se divisa cómo una indicación parlamentaria destinada a eliminar la opción del juez de aplicar la interna- 
ción en régimen semicerrado para aquellos adolescentes condenados por delitos que merezcan penas superiores a 5 años de privación de libertad, al menos durante los dos primeros años de la condena, pueda implicar una vulneración al inciso segundo del artículo $5 .^{\circ}$ de la Carta Fundamental.

En efecto, ya se ha recordado de qué manera la protección de los derechos de los adolescentes se ha encontrado especialmente presente en la gestación y desarrollo de toda la legislación sobre responsabilidad penal en que ellos puedan incurrir, la que, sin duda, ha tenido presente que, de conformidad con el artículo 37 letra b) de la Convención sobre los Derechos del Niño, no prohibe la privación de libertad de los adolescentes, sino que impide que ella sea ilegal o arbitraria, exigiendo también que sólo proceda conforme a la ley y en carácter de último recurso, por el período más breve posible, a juicio del mismo legislador.

Pero, además, debe tenerse presente que la determinación de las penas es de resorte exclusivo del legislador, al tenor de lo dispuesto en el artículo 19 n. ${ }^{\circ} 3$, incisos séptimo y octavo, de la Constitución, que señalan, el primero, que «ningún delito se castigará con otra pena que la que señale una ley promulgada con anterioridad a su perpetración, a menos que una nueva ley favorezca al afectado" $\mathrm{y}$, el segundo, que «ninguna ley podrá establecer penas sin que la conducta que se sanciona esté expresamente descrita en ella».

La competencia reservada al legislador en esta materia ha sido destacada por varias Cortes Constitucionales, pertenecientes a diversas áreas geográficas. Así, por ejemplo, el Tribunal Constitucional del Perú ha señalado que: «En materia de determinación legal de la pena, la evaluación sobre su adecuación o no debe partir necesariamente de advertir que es potestad exclusiva del legislador, junto a los bienes penalmente protegidos y los comportamientos penalmente reprensibles, el tipo y la cuantía de las sanciones penales, la proporción entre las conductas que pretende evitar, asi como las penas con que intenta conseguirlo ...en tales casos, el legislador goza, dentro de los limites de la Constitución, de un amplio margen para determinar las penas ...» (Sentencia de 21 de julio de 2005, Expediente 0019-2005-AI/TC, considerando $198 .^{\circ}$ ).

El Tribunal Constitucional de Alemania, por su parte, refiriéndose a la pena de trabajos forzados, ha afirmado que: "La ley fundamental obliga al legislador a desarrollar un concepto efectivo de la resocialización y a estructurar la ejecución de la pena con base a estos criterios. Para esto se ha dejado a él (al legislador) un amplio espacio de regulación (...) Él puede, atendiendo a toda clase de conocimientos, principalmente en los campos de la antropología, la criminología, la terapia social y la economía, llegar a una regulación que -atendiendo a los costos- se encuentre en concordancia con el rango y necesidad de otras funciones del Estado.» (Schwabe, Jürgen (compilador). Cincuenta años de jurisprudencia del Tribunal Constitucional alemán. Fundación Konrad Adenauer, Uruguay, 2003, pág. 268);

VIGESIMONOVENO: Que, igualmente, puede sostenerse que tratándose de las modalidades de cumplimiento de las penas, el legislador tiene una competencia 
exclusiva que no puede discutirse. En este sentido, el Tribunal Constitucional de España ha afirmado que respecto de "la existencia o no de medidas alternativas menos gravosas pero de la misma eficacia que la analizada, ya hemos dicho que el control de este Tribunal Constitucional tiene un alcance y una intensidad muy limitadas, so pena de arrogarse un papel de legislador imaginario que no le corresponde y de verse abocado a realizar las correspondientes consideraciones politicas, económicas y de oportunidad que le son institucionalmente ajenas y para las que no está orgánicamente concebido ...» (Sentencia 161/ 1997, de 2 de octubre de 1997, considerando 8).

Esta Magistratura, entretanto, ha invocado previamente jurisprudencia del Consejo Constitucional francés, el que, conociendo de un requerimiento que impugnaba un proyecto de ley tendiente a crear y aumentar penas, decidió que: "Dentro de los márgenes de su misión, no le cabe al Consejo Constitucional reemplazar el juicio del Parlamento por el propio con respecto a la necesidad de las penas impuestas a los delitos ...”. (Sentencia Rol n. ${ }^{\circ}$ 591, considerando 9. ${ }^{\circ}$ );

TRIGÉSIMO: Que afirmada la exclusividad de la competencia legislativa en la determinación de las penas como en la fijación de sus modalidades de cumplimiento, resulta que lo que corresponde al Tribunal Constitucional es cerciorarse de que las penas obedezcan a fines constitucionalmente lícitos y de que no se vulneren los límites precisos que la misma Carta ha impuesto como, por ejemplo, en el caso del artículo 19 n. ${ }^{\circ} 1$, que prohíbe la aplicación de apremios ilegítimos, del articulo 19 n. ${ }^{\circ} 7$, inciso segundo, letras g) y h), que impiden establecer la pena de confiscación de bienes o la de pérdida de los derechos previsionales, todo lo cual tiende, finalmente, a dar cumplimiento al deber que el inciso segundo del artículo 5..$^{\circ}$ de la Constitución impone a los órganos del Estado en orden a respetar y promover los derechos esenciales del ser humano;

TRIGESIMOPRIMERO: Que, por lo demás, esta Magistratura ha sostenido reiteradamente que el control constitucional que ejerce limita en el mérito del acto impugnado o controlado, criterio con el que coinciden los más importantes Tribunales Constitucionales del mundo y también la doctrina especializada.

En este contexto, esta Corte ha afirmado que «...el Tribunal Constitucional no legisla ni administra, ni entra a calificar la bondad de las disposiciones legales o administrativas sometidas a su control. Sólo debe resolver si dichos actos se ajustan o no a los preceptos constitucionales. De una parte, debe velar por que la ley (...) no vulnere los limites constitucionales $y$, de otra, no puede inmiscuirse en la esencia del ejercicio de la función pública que le corresponde al Congreso Nacional ...". (Sentencia Rol n. ${ }^{\circ}$ 591, considerando $9 .^{\circ}$ ).

Ha agregado que: "En el caso del legislador, tal esfera de autonomía comprende, básicamente, el conjunto de apreciaciones de mérito y oportunidad que llevan a la adopción de una u otra fórmula normativa. Sólo cuando el Parlamento exceda su ámbito de competencia, infringiendo los márgenes contemplados en la Constitución, o violente el proceso de formación de la ley, el Tribunal Constitucional puede intervenir para reparar los vicios de inconstitucionalidad en que éste haya incurrido» (Idem); 
TRIGESIMOSEGUNDO: Que en mérito de lo expuesto y no apreciándose la vulneración de los límites que la Constitución le impone al legislador para determinar penas y fijar su modalidad de cumplimiento, se desechará la vulneración alegada al artículo 5. ${ }^{\circ}$, inciso segundo, de la Carta Fundamental;

TRIGESIMOTERCERO: Que, asimismo, este sentenciador rechazará el argumento de que la norma introducida, por indicación parlamentaria, al artículo 23 n. ${ }^{\circ} 1$ de la Ley n. ${ }^{\circ} 20.084$, importa un retroceso incompatible con los compromisos internacionales asumidos por el país, en la medida que dicha norma privó al juez de la alternativa de aplicar una modalidad más benigna de ejecución de la pena, como es la internación en régimen semicerrado. Al respecto, es necesario afirmar que ello no envuelve una vulneración de derechos del sentenciado y se inserta por completo dentro de los criterios de política criminal que corresponde ponderar exclusivamente a los legisladores, según se ha sostenido en los considerandos precedentes. Si así no se entendiera, toda innovación legal que asignara una pena única a un delito anteriormente sancionable conforme a una escala gradual o que entrañara un incremento de penas o un mayor rigor en sus modalidades de cumplimiento entraría en colisión con los derechos esenciales del ser humano, lo que no puede compartirse;

La sentencia del Tribunal Constitucional largamente citada en el fondo elude un pronunciamiento sobre el locus o posición de los tratados de derechos humanos o de sus normas (artículos 3.1, 37, 40 y 41 de la Convención de Derechos del Niño y principio de no retroceso en materia de derechos humanos) o de su eficacia normativa como resultado de la regla de reenvío del artículo $5 .^{\circ}$ inciso segundo de la Constitución invocada por los requirentes en el contencioso constitucional, aunque consigna algunos planteamientos de doctrina jurisprudencial de interés, a saber:

a) El control de constitucionalidad preventivo y facultativo del n. ${ }^{\circ} 3$ del artículo 93 de la Constitución es un contencioso de control abstracto que por su naturaleza es un tipo de control que «...no tiene por objeto directo el amparo o tutela de derechos, pues no es de tal naturaleza la acción deducida» (cons. 5. ${ }^{\circ}$ )

b) En materia de fijación de penas y modalidades de cumplimento de estas existe exclusividad de la competencia legislativa.

c) Paradójicamente el sentenciador se hace cargo del derecho material planteado por lo requirentes fruto del reenvío: artículos 3.1 ,37, 40 y 41 de la Convención de Derechos del Niño, descartando, primero que el proyecto de ley sea incompatible con el principio de protección del interés superior del niño, segundo controvirtiendo el principio de prohibición de pena, ya que ésta se refiere a la prohibición de privación de libertad de 
adolescentes ilegal o arbitraria, y tercero desestima una contradicción con el principio de no retroceso en materia de garantías asumidos en compromisos internacionales, ya que la decisión del Legislador de privar al juez de la alternativa de aplicar en la ejecución de la pena un régimen más benigno como la internación en régimen semicerrado, todo lo cual guarda relación con criterios de política criminal que el propio Legislador decide.

d) Por último, el Tribunal es deferente con el Legislador y el poder político en cuestiones de mérito como el régimen o modalidad de cumplimiento de penas por adolescentes.

Finalmente, es menester también citar fragmentariamente la estructura argumentativa de la disidencia del Ministro Hernán Vodanovic Schnake, quien estuvo por acoger el requerimiento en virtud de las siguientes motivaciones:

SEGUNDO. Que el artículo 5. ${ }^{\circ}$, inciso segundo, de la Carta Fundamental establece como límite al ejercicio de la soberanía el respeto por los derechos fundamentales, obligando al Estado a respetarlos y, a la vez, a promoverlos.

En ese sentido, este Tribunal, en fallo rol 226, de fecha treinta de octubre de mil novecientos noventa y cinco, declaró que «tanto la doctrina como nuestra Constitución Politica reconocen la existencia de derechos aunque no estén consagrados en el texto constitucional, a menos que esta consagración implique una violación a las normas fundamentales.

Nuestra Carta Politica en el artículo 5. ${ }^{\circ}$, inciso segundo, establece que el ejercicio de la soberanía reconoce como limitación el respeto a los derechos esenciales que emanan de la naturaleza humana.

Esta última expresión significa que los hombres son titulares de derechos por ser tales, sin que sea menester que se aseguren constitucionalmente para que gocen de la protección constitucional.» (Considerando $25 .^{\circ}$ ).

Es decir, los derechos fundamentales tienen su fuente en la dignidad humana, y en tanto emanaciones de la misma, por una parte corresponden a todo sujeto del género humano, y por la otra cumplen una función de exigencia derivada de la necesaria protección de dicha dignidad, por lo que, a este respecto, no obsta que el texto constitucional no los contemple de forma total y expresa en el catálogo de derechos del artículo 19.

TERCERO. Que cabe, entonces, concluir que la referencia a la limitación de la soberanía por medio de los derechos fundamentales, constituye una mención abierta y genérica. Prescindiendo de si determinado derecho está o no contenido dentro del capítulo III, para establecer una definición y un marco de esta limitación material al ejercicio de la soberanía, los derechos fundamentales pueden ser conceptualizados en forma amplia como lo hace Luigi Ferrajoli, señalando que son «aquellos derechos subjetivos que corresponden universalmente a todos los seres hu- 
manos en cuanto dotados de status de personas", y, más específicamente, como "el conjunto de facultades e instituciones que concretan las exigencias de la libertad, la igualdad y la seguridad humanas en cuanto expresión de la dignidad de los seres humanos, en un contexto histórico determinado, las cuales deben ser aseguradas, promovidas y garantizadas por los ordenamientos juridicos a nivel nacional, supranacional e internacional, (H. Nogueira, Aspectos de una Teoría de los Derechos Fundamentales: La delimitación, Regulación, Garantías y Limitaciones de los Derechos Fundamentales, Ius et Praxis, v. 11 n. 2, Talca, 2005).

QUINTO. Que, una vez definido el concepto de derechos fundamentales, cabe entender que el límite al poder soberano está constituido por el conjunto de derechos que puedan entenderse incluidos en dicha definición, restando sólo establecer si los derechos invocados por los requirentes se encuentran dentro de la misma, respuesta que permitirá resolver con claridad el requerimiento de autos.

SEXTO. Que, a este respecto, la Convención de los Derechos del Niño, como todos los tratados internacionales de derechos humanos, contiene una serie de derechos y garantías consideradas como emanaciones y concreciones de la dignidad humana, que surgen en el contexto histórico de la segunda posguerra con la intención de asegurar un código jurídico mínimo de protección de la persona, aplicable a todos los seres humanos. De esa forma, es preciso inferir del concepto enunciado de derechos fundamentales y de la amplitud del alcance de la primera parte del inciso primero del artículo $5 .^{\circ}$ de la Constitución, que los derechos del menor a no ser privado de libertad por actos delictivos, a menos que sea el último recurso y por el menor tiempo; a ser tratado por el sistema penal con fines de rehabilitación y reinserción más que de mero castigo y a que se vele por el respeto efectivo de su interés superior, constituyen parte integral del conjunto de derechos fundamentales a que alude la cláusula de limitación al poder soberano contenida en el artículo $5 .^{\circ}$ de la Constitución.

OCTAVO. Que puede concluirse que las normas invocadas, en la medida que materializan derechos que son esenciales, son parte del parámetro de control de constitucionalidad aplicable en esta causa y, además, constituyen límites al ejercicio del poder soberano por parte de los órganos del Estado, en particular del legislador al ejercer su potestad de fijar penas.

DECIMOPRIMERO. Que la disposición cuestionada — en cuanto expresa un retroceso en los derechos reconocidos al menor en la legislación preexistentetransgrede principios básicos del derecho internacional de los derechos humanos, como son los de irreversibilidad y progresividad, que, respectivamente, impiden desconocer su carácter una vez que el Estado los ha reconocido y obligan a aplicar la disposición más favorable a los derechos de las personas.

Tales principios constituyen un elemento indispensable en la interpretación del cumplimiento efectivo de la norma protectora del artículo $5 .^{\circ}$ de la Constitución Política del Estado. 
La citada disidencia desde coordenadas iusnaturalistas, similares a los planteamientos del profesor Nogueira Alcalá, sostiene que los valores superiores (en especial la dignidad de la persona humana) están en la base de la norma del artículo $5 .^{\circ}$ inciso segundo de la Constitución, la que establece que el ejercicio de la soberanía reconoce como límite los «derechos esenciales que emanan de la naturaleza humana», norma iusfundamental que además preside la hermenéutica de derechos fundamentales, y que permite un reenvió a los tratados de derechos humanos, transformando a estos en derechos fundamentales implícitos (en los términos indicados en la sentencia Rol n. ${ }^{\circ} 226$, cons. $25 .^{\circ}$ de la misma Magistratura). En el fondo la disidencia apela, sin decirlo, al «bloque constitucional de derechos» para materializar los derechos humanos establecidos en tratados ratificados y vigentes, y dotarlos, bajo la modalidad de derechos implícitos, de una seudo-forma iusfundamental al incorporarlos explícitamente al parámetro o canon de constitucionalidad que el Tribunal Constitucional debe emplear al ejercer el control de constitucionalidad de los actos de poder político estatal, como son los actos del Legislador.

En este contexto el argumento relativo a los principios de irreversibilidad y progresividad propios del Derecho Internacional Convencional de los derechos humanos están demás, ya que conciernen a un plano distinto al de la materialidad iusfundamental de los derechos humanos, corresponden al plano de la eficacia normativa y estructura normativa de los tratados de derechos humanos.

\section{TRATADOS DE DERECHOS HUMANOS Y CONSTITUCIÓN. UN DEBATE PENDIENTE}

En nuestro medio, el profesor, Humberto Nogueira Alcalá es quien con más pertinacia y brillo ha sostenido la necesidad de dotar de materialidad iusfundamental a los derechos humanos señalando ${ }^{6}$ : que el Constituyente, a través de estas disposiciones se refiere a los artículos $1 .^{\circ}$ inciso $4 .^{\circ}$, artículo $5 .^{\circ}$ inciso $2 .^{\circ}$ y artículo 19 inciso $1 .^{\circ}$ y n. ${ }^{\circ} 26$ de la Constitución Política de la República, en una interpretación armónica y finalista, reconoce que los derechos no los crea ni establece el Estado, sino que ellos emanan directamente de la dignidad y la naturaleza del ser humano; por lo tanto, el Constituyente sólo se limita a reconocer tales derechos y a asegurarlos, a darles protección jurídica, a garantizarlos. Si ta-

6 «Los tratados internacionales en el ordenamiento jurídico chileno»,en Revista Chilena de Derecho, Vol. 23 n. ${ }^{\text {s }} 2$ y 3 Tomo I., Facultad de Derecho, Pontificia Universidad Católica de Chile, Mayo-agosto 1996, pp. 351 y ss. 
les derechos emanan de la naturaleza humana, ellos pertenecen al hombre por el sólo hecho de ser persona y, por lo tanto, tales derechos tienen la característica de ser universales, absolutos, e imprescriptibles. Puede sostenerse, además, que los derechos que emanan de la naturaleza humana no pueden ser enumerados taxativamente de una vez y para siempre, por cuanto los seres humanos en el desarrollo histórico y de su conciencia podrán ir perfeccionado los existentes y desarrollando otros nuevos. De ello se dejó expresa constancia en las actas oficiales de la Comisión de Estudios de la Nueva Constitución, en su sesión 203. «La protección constitucional se refiere no sólo a los derechos establecidos en ella, sino que a todos los que son inherentes a la naturaleza humana», como asimismo se reconoció que tales derechos no son sólo los enumerados en el texto de la Constitución, en los capítulos segundo y tercero, «sino también los que formen parte del acervo cultural de la humanidad y que son propios de la naturaleza humana». Una afirmación similar hace el Pacto Internacional de Derechos Civiles y Políticos en su artículo $5 .^{\circ}$, pudiendo ser ampliados los derechos contenidos a otros que establezcan otros pactos posteriores, Así, la Constitución establece en su artículo $5 .^{\circ}$ inciso $2 .^{\circ}$, en forma expresa; dos modalidades de institucionalización de derechos naturales, la propia norma constitucional y el tratado internacional, siendo esta última la modalidad que permite incorporar a la constitución material los derechos naturales que no están expresamente contenidos en el texto constitucional o no se hayan incorporados formalmente a ella a través del procedimiento de reforma de la Ley Suprema».

Más adelante se refiere a la institucionalización de derechos humanos mediante tratados internacionales, señalando lo siguiente: «Ratificado un tratado internacional en materia de derechos humanos, previa aprobación del Congreso, y siempre que el tratado se encuentre vigente en el ámbito internacional y nacional, ello produce las siguientes consecuencias en el ordenamiento jurídico nacional:

De acuerdo al artículo $5 .^{\circ}$ inciso $2 .^{\circ}$ de la Constitución, los derechos naturales asegurados en el tratado se incorporan al ordenamiento jurídico interno, formando parte de la Constitución material y adquiriendo plena vigencia, validez y eficiencia jurídica, no pudiendo ningún órgano del Estado desconocerlos y debiendo todos ellos respetarlos y promoverlos, como asimismo, protegerlos a través del conjunto de garantías constitucionales destinadas a asegurar el pleno respecto de los derechos... Esta obligación no sólo se deriva del artículo $5 .^{\circ}$ de la Constitución, sino también de los mismos tratados internacionales, entre éstos del artículo 1. ${ }^{\circ}$ común a los Cuatro Convenios de Ginebra, de 1949, que establece el deber de los Estados Partes de respetar y hacer respetar el Derecho Internacional Humanitario, lo que ha sido judicialmente reconocido por la Corte Internacional de Justicia de La Haya, en el caso de Nicaragua-Estados Unidos, 
donde la Corte estableció el deber de los Estados Unidos de respetar y hacer respetar dichos convenios «en todas las circunstancias», lo que deriva no sólo de tales convenios, sino de los principios generales del derecho humanitario, a los cuales los convenios dan expresión concreta ${ }^{7}$.

También se refiere Nogueira Alcalá a la diferenciación entre tratados y tratados de derechos humanos, indicando lo siguiente: «En materia de tratados sobre derechos humanos, éstos tienen características especiales que los diferencian de otro tipo de tratados, como lo ha señalado la Corte Internacional de Justicia» en ellos los Estados contratantes no tienen intereses propios, tienen solamente, todos y cada uno de ellos, un interés común, que es el de preservar los fines superiores que son la razón de ser, de la Convención. En una Convención de este tipo no puede hablase de ventajas o desventajas individuales de los Estados, ni de mantener un equilibrio contractual exacto entre derechos y deberes. La consideración de los fines superiores de la Convención es, en virtud de la voluntad de las partes, el fundamento y medida de todas sus disposiciones». Esta concepción de los tratados en materia de derechos humanos es sostenida también por la Corte Interamericana de Derechos Humanos, al establecer «que estos instrumentos no son, tratados multilaterales de tipo tradicional concluido en función de un intercambio recíproco de derechos, sino el beneficio mutuo de los Estados contratantes. Su objetivo y fin son la protección de los derechos fundamentales de los seres humanos independientes de su nacionalidad tanto frente a su propio Estado como frente a los otros Estados contratantes. Al aprobar estos tratados sobre derechos humanos, los Estados se someten a un orden legal dentro del cual ellos, por el bien común, asumen varias obligaciones, no en relación con los Estados, sino hacia los individuos bajo su jurisdicción». A su vez, es necesario precisar desde la perspectiva del derecho convencional internacional establecido en la Convención de Viena sobre Derechos de los Tratados, de 1969, el que se encuentra ratificado por Chile y vigente, que establece en el artículo 60, que se excluye todo tipo de reciprocidad para las disposiciones relativas a protección de las personas en los tratados humanitarios, lo que aplica también a las Convenciones de Derechos Humanos.

Recuerda finalmente Nogueira Alcalá que la Corte Permanente de Justicia Internacional ha resuelto que «es un principio de Derecho de Gentes generalmente reconocido que, en las relaciones entre potencias contratantes, las disposiciones del derecho interno no pueden prevalecer sobre las de un tratado» (Se-

7 Citando a Antonio Caneado Trindade en «Desarrollo de las relaciones entre el Derecho Internacional Humanitario y la Protección Internacional de los Derechos Humanos en su amplia dimensión». Revista IIDH n. ${ }^{\circ}$ 16, San José de Costa Rica, 9+ párrafos 181-182, pp. 73-74. 
rie B n. ${ }^{\circ} 17$ p. 32 Ver, asimismo, los artículos 27 y 46 de la Convención de Viena sobre el derecho de los tratados, de 1969); y que «Un Estado no puede invocar frente a otro su propia Constitución para sustraerse a las obligaciones que impone el Derecho Internacional a los tratados vigentes».

A mi juicio, más allá de las disputas en el Derecho Internacional de escuelas entre monistas y dualistas, la posición sostenida por Nogueira Alcalá en nuestro medio incurre en un yerro capital para el análisis de esta compleja cuestión: omite a la Constitución como pieza básica en la determinación del locus de los tratados internacionales en el sistema de fuentes del orden nacional. En efecto, es la Constitución estatal, concebida como un conjunto de reglas de competencia, la que define la regla de incorporación - regla de habilitación del Derecho de los tratados en el Derecho interno, así como la posición y controles de constitucionalidad a que deben someterse los tratados internacionales, cuando corresponda.

Reincide Nogueira Alcalá en el yerro al conexionar la incorporación del Derecho de los tratados con la unidad y primacía del Derecho Internacional general y las reglas imperativas o de ius cogens; tratando esto como un todo o reductio ad unum. Ningún conjunto de «alardes hermenéuticos»o «simple proceso semántico" puede extraer del artículo $5 .^{\circ}$ inciso segundo párrafo segundo una regla que permita un orden competencial distinto al fijado en la Constitución o una jerarquía supraconstitucional de tratados de derechos humanos o simplemente un "bloque constitucional de derechos», conducente a quebrar la supremacía de la Carta, su valor y eficacia normativa, su rigidez, procedimiento de reforma constitucional y control de constitucionalidad. Tampoco podemos extraer de la anotada regla de incorporación un supuesto de «autorruptura» constitucional, que pudiere importar la remisión en la producción del derecho a una instancia ajena que «no entiende» de Constitución, que «pasa» de Constitución, y que se tradujere en la producción de normas (convencionales) de derechos humanos, directamente aplicables a todo el territorio y a toda la población.

Coronación de los argumentos expuestos es la filiación iusnaturalista de los «derechos esenciales» que emanan de la «naturaleza humana», y su mentada funcionalidad limitativa del ejercicio de la soberanía a través de poderes constituidos (funcionalidad que pretende o amenaza extenderse incluso al Poder Constituyente originario), contribuyen a un verdadero «reino de la confusión», que olvida muchas veces lo elemental ${ }^{8}$.

8 Vanossi, J. R.; Dalla Via, A. R. Ob. Cit. p. 25, y Ríos Alvarez, Lautaro: «Jerarquía Normativa de los Tratados Internacionales sobre Derechos Humanos», Gaceta Jurídica n. ${ }^{\circ} 215$, pp. 7-14. Sobre el Derecho internacional general y la categoría de ius cogens, opuesta al ius dispositivum, consultar a Michel Virally: «El Devenir del Derecho Internacional. Ensayos escritos al correr de los años» (trad. E. Casenave Tapie Isoard), Edit. F.C.E., México DF, 1998, en especial pp. 164-189. 
La Constitución estatal y su regla de incorporación o recepción de tratados internacionales (artículo $32 \mathrm{n} .{ }^{\circ} 15 \mathrm{y}$ artículo 54 n. ${ }^{\circ} 1$ C.P.R.) es una dato de derecho positivo insoslayable para abordar esta cuestión, y a partir de este dato podemos determinar el locus del tratado en general y del tratado o de las normas de tratados relativas a derechos humanos en particular.

El control de constitucionalidad del tratado internacional por el Tribunal Constitucional, de tipo preventivo, obligatorio y facultativo respectivamente, previsto en los n. ${ }^{\circ} 1 \mathrm{y} \mathrm{n}^{\circ} 3$ del artículo 93 de la Carta es una consecuencia directa, de la inclusión en la Constitución de una regla de incorporación del Derecho de los tratados.

Lo anterior no significa renunciar a una posición teórico-práctica garantista y privar de valor normativo y eficacia normativa a la norma del artículo $5 .^{\circ}$ inciso segundo, parte segunda de la Constitución, que hace la diferencia con tratados internacionales de derechos humanos. Esta cláusula de reenvío no tiene la virtualidad de modificar la «jerarquía» de los tratados de derechos humanos o las normas de tratados sobre dicha materia, no empece ni puede empecer a la validez de esta fuente de Derecho Internacional, sino que califica la eficacia de estas fuentes en el Derecho interno, ya que establece una valiosa garantía institucional genérica en orden a que los órganos del Estado deben respetar y promover derechos fundamentales y derechos humanos, todo lo cual debe ser armonizado con la posición de aplicación preferente que tienen los tratados en el Derecho interno y su especial resistencia pasiva frente a fuentes formales de Derecho interno. Todo ello importa establecer la estructura normativa de los tratados, para determinar su valor y eficacia normativa en el Derecho interno, sin perjuicio de sus efectos de Derecho Internacional'

Así para abordar la estructura normativa y efectos de los tratados internacionales resulta pertinente distinguir, como lo hace el Tribunal Constitucional claramente entre disposiciones o cláusulas «autoejecutables» o «self executing» y disposiciones «no autoejecutables» $\mathrm{o}$ «non self executing» de un tratado, de la siguiente manera: «48. ${ }^{\circ}$ a) Los tratados, para su aplicación en el orden interno de un país, pueden contener dos tipos de cláusulas, denominadas por la doctrina «self executing» $y$ «non self executing». Las primeras son las que tienen el contenido y precisión necesarias que las habilita para ser aplicadas sin otro trámite como fuente del derecho interno. En otros términos, son autosuficientes, y entran a la legislación nacional cuando el tratado que las contiene se incorpora al derecho vigente. Las segundas, son aquellas que requieren para su entrada en vi-

9 Reuter, Paul: «Introducción al Derecho de los Tratados» (trad. E.L Suárez y revisión P. Haggenmacher), Edit. F.C.E.- UNAM, México DF. 1999, en especial, pp. 116-190. 
gencia de la dictación de leyes, reglamentos o decretos que las implementen y, en tal evento, las haga aplicables como fuente del derecho interno. En otras palabras, imponen la obligación al Estado, para que en uso de sus potestades públicas, sancione la normativa necesaria para que por esta vía les dé vigencias efectiva» (Rol n. ${ }^{\circ}$ 309-2000). Subyace a lo dicho sobre el tipo de cláusulas convencionales y su ejecutividad, la distinción entre tratados solemnes, bilaterales o multilaterales y tratados simplificados o acuerdos de ejecución, siendo los primeros los que requieren aprobación parlamentaria, y los segundos de resorte de los poderes exteriores gubernativos-administrativos del Presidente de la República (artículo $54 \mathrm{n} .^{\circ} 1$, inciso $4 .^{\circ}$ y artículo 32 n. ${ }^{\circ} 15$ C.P.R.).

De acuerdo a ello, las cláusulas que contienen los tratados enuncian normas de diversa densidad normativa o alcance, categoría y, por lo tanto, efectividad; «hay normas cuya aplicación directa no importa mayor problema, toda vez que su redacción es tajante, no requieren ser detalladas legislativamente y, por lo general, no admiten excepciones... En otras ocasiones, las normas poseen un contenido genérico y abstracto que requieren posteriores actos legislativos internos que las detallen o hagan posible su aplicación a casos concretos, generalmente son mandatos al legislador... ${ }^{10}$.

Tenemos, entonces, que los tratados internacionales pueden contener disposiciones o cláusulas autoejecutivas y cláusulas que no sean autoejecutivas, o sólo unas u otras, y que para definir si son de uno u otro tipo habrá que estarse al contenido específico de cada tratado internacional y de sus cláusulas o normas particulares.

Finalmente, debe tenerse en consideración que en nuestro medio los tratados internacionales vigentes y ratificados por el Estado de Chile, es decir, incorporados al ordenamiento jurídico interno, no tienen jerarquía de ley ordinaria sino un lugar en el sistema de fuentes determinadas a partir del principio de aplicabilidad, pero nunca podrán ser contrarios a la Constitución Política de la República (art. 5. ${ }^{\circ}$ C.P.R.). Así lo confirma nuestro Tribunal Constitucional en una sentencia antes citada:

a) «La prevalencia, en el orden interno, de los preceptos constitucionales sobre las disposiciones de un tratado resulta, por lo demás, del todo consecuente con el sistema jurídico, ya que la interpretación contraria permitiría la reforma de la Carta Fundamental por un modo distinto del establecido en sus artículos 116 al 118. De allí que dicha prevalencia, tanto en la doctrina nacional como ex-

${ }^{10}$ Carmona Tinoco, Jorge: «La aplicación Judicial de los Tratados Internacionales», Derecho Internacional de los Derechos Humanos, Memoria del VII Congreso Iberoamericano de Derecho Constitucional, Instituto de Investigaciones Jurídicas, México 2002, pp. 181-209. 
tranjera, sea la generalmente aceptada, salvo en aquellos casos excepcionalísimos en que la propia preceptiva constitucional respectiva establezca lo contrario» (21 diciembre 1987, Rol n. ${ }^{\circ} 46$ ).

b) «61. Q Que, con anterioridad a la reforma de 1989, había opinión unánime en el sentido que los tratados internacionales estaban sujetos al principio de supremacía constitucional».

«62. Que, en este aspecto, es relevante recordar, que aunque aparezca obvio, la norma constitucional reformada no consagró que los tratados internacionales sobre derechos esenciales tuvieran una jerarquía igual o superior a la Ley Fundamental».

«63. ${ }^{\circ}$ Lo anterior nos permite afirmar que no estuvo en la mente del Constituyente que los tratados no quedaran sujetos a la supremacía de la Constitución ni menos que su jerarquía permitiera enmendar normas de la Ley Fundamental, ya que si así no fuere carece de toda explicación lógica y jurídica que se hubiere afirmado que era procedente el recurso de inaplicabilidad de una norma de un tratado por ser contraria a la Constitución, habida consideración que dicho recurso reconoce como causa inmediata, precisamente, la prevalencia de la Constitución sobre la ley o el tratado».

«64. ${ }^{\circ}$ Que con anterioridad a la reforma de 1989 este Tribunal, en sentencia de 21 de diciembre de 1987, Rol n. ${ }^{\circ}$ 46, señaló expresamente que las normas constitucionales, en el orden interno, prevalecen sobre las disposiciones contenidas en tratados internacionales».

«68. ${ }^{\circ}$...Dicha pretensión también atenta contra el delicado mecanismo de reforma de la Carta Fundamental, contenido en un capítulo especial, el Capítulo XIV, y que se caracteriza por su notable rigidez, especialmente tratándose de la reforma del capítulo relativo a los derechos y deberes constitucionales, cuya estabilidad y preservación el constituyente aseguró exigiendo un quórum reforzado de las dos terceras partes de los diputados y senadores en ejercicio.

Tanto este quórum especial como los trámites propios de una ley y de reforma quedarían reemplazados por el quórum y los trámites de una ley ordinaria que, además, tendría el efecto de reformar la Constitución si aceptáramos el rango constitucional de los tratados sobre derechos humanos y su eventual carácter modificatorio de la Constitución.

«Una interpretación semejante, para ser armónica con el resto de la preceptiva constitucional, debiera haberse plasmado en un texto diferente y debiera haber venido acompañada de la modificación de los arts. 80, 82 n. 2 y del Capítulo XIV de la Constitución» ("Jerarquía Normativa de los Tratados Internacionales sobre Derechos Humanos», en Gaceta Jurídica n. ${ }^{\circ}$ 215, 1998, pág. 13)».

"69. ${ }^{\circ}$ Que sostener que los tratados internacionales sobre derechos humanos puedan modificar la Constitución, conduce a que pierdan eficacia las disposiciones que permiten el control previo de constitucionalidad de los tratados (artículo 82, n. $^{\circ} 2$, de la Constitución) y el control a posteriori (artículo 80, de la 
Constitución) ¿pues qué sentido tendrían estos controles si las normas del tratado sobre derechos humanos tuvieren el mismo rango jerárquico que la Constitución?» (8 abril 2002, Rol n. ${ }^{\circ}$ 346).

Lo anteriormente expuesto exige una breve explicación. Los tratados internacionales, relativos a derechos humanos como los relativos a cualquier otra materia, son una importante fuente de Derecho Internacional Convencional. Los tratados en virtud de los principios-reglas de Derecho Internacional General y Convencional de "pacta sunt servanda» y «bona fide» recogidos en la Convención de Viena sobre Derecho de los Tratados de 1969, obliga a lo estipulado en sus cláusulas o normas y al cumplimiento de buena fe de sus cláusulas por parte de los Estados partes o signatarios. La infracción de estos principios trae aparejada responsabilidad de Derecho Internacional para los Estados signatarios recalcitrantes. De esta suerte, el tratado internacional a pesar de no tener jerarquía en el Derecho interno, goza de una posición de eficacia o aplicabilidad preferente por los órganos del Estado, y de una especial resistencia pasiva a la fuerza derogatoria o modificatoria de fuentes de derecho como la ley, por lo que su «derogación» o modificación o suspensión (denuncia), sólo puede producirse en la forma prevista por el propio tratado o el Derecho Internacional, como muy apropiadamente lo dispone el artículo $54 \mathrm{n} .^{\circ} 1$, inciso quinto, de la Constitución, reformada el año 2005. Se trata de una verdadera «inderogabilidad» del tratado frente a la ley. Queda pendiente el espinoso tema de la «fuerza de ley» del tratado, sea pasiva o activa y de la solución al conflicto de normas.

Sin embargo, a partir de estas definiciones elementales la operatividad o efectividad de los tratados y sus cláusulas en el Derecho interno, debe ponderarse empleando la distinción elemental entre normas o cláusulas autoejecutivas y no autoejecutivas.

En consecuencia, como lo hemos expuesto, los tratados, que son fuente de Derecho Internacional Convencional, carecen en el Derecho interno de jerarquía y su incorporación al Derecho interno en virtud del artículo 54 n. ${ }^{\circ} 1$ de la Constitución obliga al Estado a conferirle eficacia o aplicabilidad preferente a sus cláusulas o normas. En todo caso, el tratado, lo que es confirmado por la jurisprudencia constitucional, se encuentra sujeto a la Constitución e incluso más, sometido a un control de constitucionalidad preventivo y obligatorio y a un control de constitucionalidad preventivo y facultativo, en virtud del artículo $93 \mathrm{n}$. $^{\circ}$ 1 y n. 3 de la Carta Fundamental.

Como se ha dicho, la operatividad o efectividad de los tratados incorporados al Derecho interno debe ir de la mano de un examen acerca del carácter autoejecutivo o no autoejecutivo de sus cláusulas o normas, examen que pasa por de- 
terminar la densidad normativa, alcance y relaciones jurídicas que tales cláusulas o normas fijan. De este modo, la autoejecutividad de las cláusulas o normas de los tratados internacionales exige un examen de la estructura normativa de estos y además de adecuación de éstos a la Constitución Política de la República.

Luego, las cláusulas no autoejecutivas del tratado internacional obligan al Estado signatario o parte a adoptar medidas de ejecución y de adecuación de Derecho interno, sin perjuicio de la suscripción de acuerdos o convenios de implementación, o la dictación de decretos con fuerza de ley de ejecución, en los términos del artículo 54 n. ${ }^{\circ} 1$ inciso final, de la Constitución. Tales poderes exteriores, permiten la adopción de acuerdos de ejecución de tratados internacionales, la celebración de tratados simplificados o acuerdos en ejercicio de la potestad reglamentaria, y también el ejercicio de potestad legislativa delegada, cuando el acuerdo aprobatorio de un tratado lo habilite a dictar decretos con fuerza de ley necesarios para su cumplimiento.

En suma, los poderes exteriores del Presidente de la República, reequilibrados en lo concerniente a la relación Gobierno-Congreso Nacional por la reforma constitucional de 2005, conservan su anclaje en el principio monárquico propio del régimen presidencialista, coadyuvando al déficit democrático de los tratados, dado el estrecho margen de deliberación-decisión implicados en la aprobación parlamentaria de los tratados.

\section{CONCLUSIONES}

La jurisprudencia comentada permite sostener en primer lugar un «antes» $\mathrm{y}$ un «después» en materia de tratados internacionales de derechos humanos, en relación a la reforma constitucional de 2005 promulgada mediante la Ley n. ${ }^{\circ}$ 20.050 .

$\mathrm{El}$ «antes» esta recogido en las sentencias del Tribunal Constitucional recaída en el caso Almeyda y en la referida al contencioso constitucional acerca del Tratado que fija el Estatuto de Roma de la Corte Penal Internacional, que afincada en el principio dogma de la soberanía y a través de un obiter dicta desestima la jerarquía supraconstitucional o constitucional de los tratados. Además, esta doctrina jurisprudencial admitía un control de constitucionalidad represivo de tratados internacionales vía recurso de inaplicabilidad del artículo 80 .

$\mathrm{El}$ «después» se da en el marco de la jurisprudencia del Tribunal Constitucional posterior a la reforma constitucional de 2005 tanto en sentencias concernientes a control concreto de constitucionalidad como en control abstracto de constitucionalidad y que ejemplarmente se contiene en la sentencia recaída en el 
contencioso constitucional incoado a raíz de la aprobación de un artículo nuevo en el proyecto de ley que modifica la Ley ${ }^{\circ}{ }^{\circ} 20.084$ que estable un sistema de responsabilidad de los adolescentes por infracción a la ley penal.

$\mathrm{El}$ «después» es un "compás de espera», ya que la sentencia comentada elude entrar a una definición acerca del locus (jerarquía) de los tratados internacionales de derechos humanos, aunque en relación a la eficacia normativa de tales tratados, en la que también elude entrar a una definición, se explaya acerca de la autoejecutividad, contenido y densidad de las normas convencionales ${ }^{11}$.

Para eludir tales definiciones el Tribunal Constitucional se limita a formular un conjunto de definiciones, a saber:

a) El control de Constitucionalidad no es un proceso de constitucionalidad que por su naturaleza persiga la tutela diferenciada de derechos fundamentales.

b) Los controles de constitucionalidad tienen como límite institucional la deferencia razonada del Tribunal Constitucional con el legislador y con la competencia legislativa, de suerte que existe un amplio margen a la determinación normativa de conductas, en la especie e imposición de penas y el régimen de cumplimiento de éstas como es la internación en régimen semi cerrado o cerrado tratándose de población adolescente.

Tales definiciones resultan insuficientes, ya que si el Tribunal Constitucional desestima la doctrina de la «jerarquía» constitucional de los tratados de derechos humanos o de su materialidad iusfundamental a través de un «bloque de constitucionalidad», lo que debe hacer es fijar los alcances de la garantía institucional genérica del artículo $5 .^{\circ}$ inciso segundo de la Constitución, poniendo de relieve la eficacia normativa de los tratados incorporados al Derecho interno, específicamente su regla de prevalencia (aplicación preferente) frente a las fuentes formales de Derecho interno, la resistencia pasiva de los tratados frente a la fuentes de Derecho interno y la imposibilidad de un control de constitucionalidad represivo.

Finalmente, es menester destacar la disidencia contenida en la sentencia Rol n. ${ }^{\circ}$ 693, ya que ésta opta, por poner fin a este "compás de espera», otorgándole a los tratados internacionales sobre derechos humanos materialidad iusfundamental y una seudoforma iusfundamental, e incorporando los derechos implícitos (normas de tratados internacionales de derechos humanos) al parámetro o canon de constitucionalidad que utiliza el Tribunal Constitucional.

${ }^{11}$ Peña Torres, Marisol: «Cuatro Estudios de Justicia Constitucional» Edic. Cuadernos del Tribunal Constitucional, Santiago, 2007. 
Para concluir, resulta pertinente puntualizar que el Tribunal Constitucional tibiamente en otra sentencia recaída en control concreto de constitucionalidad (STC Rol n. ${ }^{\circ}$ 561-2006 ) fija una doctrina jurisprudencial acerca del artículo 5. ${ }^{\circ}$ inciso segundo de la Constitución como garantía institucional genérica de derechos fundamentales y derechos humanos y desecha la posibilidad de ampliar el parámetro de constitucionalidad con normas infraconstitucionales invocadas por la requirente como derecho material. Al respecto la sentencia dispone:

QUINTO: Que, como ya se expresó en esta sentencia, las normas constitucionales que se estiman infringidas por el requirente son el artículo $19 \mathrm{n} .{ }^{\circ} 3$, el artículo 61 y el artículo $5 .^{\circ}$, todas de la Constitución Política de la República, artículos de tratados internacionales que se citan y los artículos $4 .^{\circ}$ y $5 .^{\circ}$ del Código Procesal Penal, normas estas últimas que por ser de rango legal no son susceptibles de ser consideradas como parámetro de este control.(...) Por su parte, el artículo $5 .^{\circ}$ de la Constitución consagra en su inciso primero el principio de soberanía de la democracia constitucional y en su inciso segundo la función limitativa del ejercicio de la soberanía que cumplen los derechos fundamentales en particular y los derechos humanos en general, y al mismo tiempo consagra una garantía institucional de respeto y promoción de tales derechos por los órganos del Estado; disponiendo así en el citado inciso segundo lo siguiente: «El ejercicio de la soberanía reconoce como limitación el respeto de los derechos esenciales que emanan de la naturaleza humana. Es deber de los órganos del Estado respetar y promover tales derechos, garantizados por esta Constitución, asi como por los tratados internacionales ratificados por Chile y que se encuentren vigentes».

SEXTO: Que el requirente invoca como normas constitucionales infringidas las reglas relativas a presunción de inocencia establecidas en fuentes del ordenamiento infraconstitucionales, como los artículos $4 .^{\circ}$ y $5 .^{\circ}$ del Código Procesal Penal. Esta Magistratura Constitucional, que posee una competencia tasada como órgano de control de constitucionalidad de normas y actos estatales en los términos del artículo 93 de la Constitución, debe precisar que las normas de fuentes del ordenamiento infraconstitucionales no constituyen derecho material que sirva de parámetro para construir el juicio de constitucionalidad en un proceso, sin perjuicio de la importancia que tienen tales fuentes como niveles de protección de derechos de las personas en el ordenamiento jurídico y de que reflejen el grado de desarrollo que adquieren los valores, principios y bienes jurídicos iusfundamentales»;

En suma el tema sigue abierto, una suerte de "compás de espera», en la doctrina jurisprudencial del Tribunal Constitucional y la invitación del ponente, desde una posición teórico-práctica garantista, es a «tomarse en serio» los tratados internacionales en general y los tratados internacionales de derechos humanos en particular, definiendo para los tratados una posición infraconstitucional, pero prevalente entre las fuentes formales de Derecho interno por aplicación pre- 
ferente, en especial de las normas autoejecutivas de los tratados. En este sentido, se puede sostener la fuerza normativa supralegal de los tratados internacionales, no por jerarquía sino por aplicación preferente y resistencia pasiva, y además puede sostenerse que tratándose de los tratados de derechos humanos ratificados y vigentes en particular, estos importan una vinculación calificada de los poderes públicos (órganos del Estado, supremos y no supremos), que adopta la forma de una garantía institucional genérica de imposición de deberes de respeto y promoción de los derechos humanos de fuente convencional internacional. Junto a ello debemos dar cuenta de la necesidad de desarrollo normativo legal e infralegal de los tratados internacionales cuando fuere procedente en cumplimento de los principios básicos de pacta sunt servanda y bona fide.

\section{APOSTILLAS. TRATADOS Y CONSTITUCIÓN}

Los tratados internacionales desde los inicios de la modernidad, con la paz de Westfalia, han representado un arduo problema para la teoría del Derecho en general, y para el Derecho de Gentes primero (Redslob) y para el Derecho Constitucional más tarde, llegándose a hablar en la Europa de entreguerras, con la esperanza de un nuevo orden de paz y libertad, de un «Derecho Constitucional Internacional» (Mirkine Guetzevitch), lo que nos obliga a tomarnos en serio en los planos teórico-prácticos los tratados y a reconocer que las técnicas de adaptación o recepción tienen un contexto específico en cada orden jurídico estatal ${ }^{12}$.

Entre estos problemas complejos, arduos, que a veces nos parecen insolubles, están precisamente: el de la relación tratado-Constitución y el de la formación del tratado como fuente del Derecho o mejor dicho en la plástica expresión de lengua inglesa "treaty making power»; problemas a los que me referiré sucintamente.

En cuanto a la relación tratados-Constitución M. Virally nos señala las exactas coordenadas de las aproximaciones al tema: «En cuanto a los tratados, existen dos enfoques posibles, que dependen de las disposiciones constitucionales aplicables. Algunos sistemas constitucionales exigen que antes de poder aplicar

${ }^{12}$ Mirkine Guetzevitch, Boris: «Droit Constitutionnel International» Paris, 1933 (versión castellana por L. Legaz L. de la Editorial de Derecho Privado, Madrid, 1936, pp. 25 y ss.). El mismo jurista ruso francés al identificar las nuevas tendencias constitucionales indica: "Esto hace insistir que, en las nuevas Constituciones, las tendencias internacionales son expresadas con una fuerza extraordinaria, tanto en el procedimiento de declaración de guerra y de la conclusión de tratados que en el sentido de introducir en las Constituciones, el reconocimiento de la fuerza obligatoria del Derecho Internacional», en "Las Nuevas Constituciones del Mundo», Editorial España, Madrid, 1931, p. 40. Redslob, Robert: «Histoire des Grands Principes du Droit Des Gens» Rousseau et. Cie. Editeurs, Paris, 1923, pp. 213-217. 
como derecho interno cualquier disposición de un tratado — aún cuando el tratado haya sido ratificado con la aprobación del poder legislativo- debe ser incorporado al derecho interno mediante la correspondiente legislación. Éste es el sistema dualista, de acuerdo con el cual los tribunales del ordenamiento jurídico interno sólo aplican la legislación interna aprobada para poner en vigor el tratado, y no el tratado mismo, y pueden hacerlo únicamente en tanto dicha legislación esté vigente. Ésta todavía es la situación en el Reino Unido — por lo menos formalmente- como resultado de la naturaleza de las relaciones entre la Corona y el Parlamento. Por otra parte, muchas de las constituciones modernas (como la de los Estados Unidos) disponen que los tratados debidamente celebrados tendrán la vigencia del derecho interno y obligarán directamente, tanto a las personas como a los tribunales. Disposiciones de esta clase convierten a los tratados celebrados por el Estado en una fuente de derecho interno (véase, por ejemplo, el artículo 55 de la Constitución Francesa del 4 de octubre de 1958). Pero, en algunos casos, la posibilidad de aplicar los tratados como derecho interno se hace depender del cumplimiento de ciertas formalidades, tales como la promulgación en la misma forma que las leyes (aunque este requisito ha desaparecido en casi todas partes) o la publicación en la gaceta oficial. A veces se requiere reciprocidad, en el sentido de que un tratado no será aplicable como derecho interno en un Estado a menos que sea igualmente aplicado por las otras partes (cf. el artículo 55 de la Constitución francesa ya referido). Sin embargo, estas diferencias de procedimiento no alteran el hecho de que, dentro de un marco constitucional del tipo descrito, los tratados constituyen una fuente tanto de derecho interno como de derecho internacional (cf. de Visscher, «Les Tendances internacionales des constitutions modernes», $80 \mathrm{HR}, 511(1952)^{13}{ }^{\prime}$.

El propio Kelsen en su monumental obra «Principios de Derecho Internacional Públicos» nos señala: "la solución al problema de si un tratado ha sido concluido de acuerdo con la Constitución del Estado contratante depende de la interpretación de la Constitución; y está dentro de la competencia del Gobierno interpretar, en su relación con otros Estados, su propia Constitución» (...) «El comienzo de la validez del tratado como norma coincide con la terminación del procedimiento que llamamos tratado... en ese momento el tratado adquiere fuerza obligatoria... la fuerza obligatoria del tratado se manifiesta en que las partes contratantes no pueden unilateralmente librarse de las obligaciones estipu-

${ }^{13}$ Contribución de M. Virally en el capítulo de fuentes del derecho del derecho Internacional en libro colectivo editado por Max Sorensen: «Manual de Derecho Internacional Público» (revisión y adiciones de B. Sepúlveda), Edit. F:C:E., 1. ${ }^{a}$ edic. 1973, 2. ${ }^{a}$ reimpresión, 1981 México DF., 1980, p. 193. 
ladas por el tratado, a menos que éste autorice a cada parte a separarse según precisas condiciones determinadas por el tratado ${ }^{14}$.

Con antelación el mismo Kelsen en la justificación teórica de la Jurisdicción Constitucional por un tribunal especializado y supremo, había sostenido con cierto desgano realista la posibilidad de control de constitucionalidad de tratados internacionales. «Nada se opone, nos dice Kelsen, jurídicamente a que la Constitución de un Estado le atribuya esta competencia, con el poder de anular los tratados que juzgue inconstitucionales. A favor de esta extensión de la justicia constitucional podrían invocarse argumentos no desdeñables (...) Ninguna regla de Derecho internacional se opone a este control de los tratados. Si, como debe admitirse, el Derecho internacional autoriza a los Estados a determinar en sus constituciones qué órganos pueden en exclusiva celebrar válidamente tratados, es decir, celebrarlos de forma que obliguen a las partes contratantes, no puede ser contrario a Derecho internacional crear una institución que garantice la aplicación de normas que este Derecho autoriza» ${ }^{15}$.

También los tratados plantean un problema ligado a la Constitución estatal a propósito del «treaty making power». El mismo Kelsen nos recuerda que el tratado es un acuerdo concertado normalmente por dos o más Estados conforme al Derecho Internacional y la voluntad del Estado «se expresa por medios de un individuo que actúa en su capacidad de órgano del Estado» ${ }^{16}$. Agrega en otro lugar el maestro vienés: «Las constituciones contienen en general prescripciones sobre su elaboración, autorizando al jefe de Estado a celebrarlo, acordando al Parlamento la facultad de ratificarlo, exigiendo para su validez interna su transformación en leyes, etc. Los principios constitucionales sobre el contenido de las leyes valen igualmente para los tratados internacionales $\mathrm{o}$, al menos, pueden valer para ellos, pues es concebible también que el Derecho positivo los exceptúe de estas disposiciones. Los tratados internacionales deben ser vistos como manteniendo con la Constitución exactamente la misma relación que las leyes. Pueden ser inmediatamente inconstitucionales, tanto formalmente — por razón de su elaboración - como materialmente — por razón de su contenido—» ${ }^{17}$.

Esta conexión del tratado con la Constitución que mira a la relación Gobierno-Parlamento, relación marcada por el archisabido déficit democrático, tan-

${ }^{14}$ Kelsen, Hans: «Principios de Derecho Internacional» (trad. H. Caminos y E.C. Hermida) Edit. Ateneo, Buenos Aires, 1965, pp. 277 y 333.

15 Kelsen, Hans: «La Garantía jurisdiccional de la Constitución. (La Justicia Constitucional)» en recopilación bajo el título "Escritos sobre la Democracia y el Socialismo» (Selección y presentación Juan Ruiz Manero), edit. Debate, Madrid, 1988, p. 136.

16 Kelsen, Hans: «Principios...», ob. cit., pp. 271-272.

17 Kelsen, Hans: «La Garantía...», ob. cit., p. 119. 
to en el plano nacional como internacional, exige la sujeción de estos instrumentos a la Constitución y los controles de constitucionalidad del tratado. Sobre este particular Oppenheim desde una perspectiva pragmática señala: «Aún cuando los jefes de Estado sean regularmente, con arreglo al Derecho Internacional, los órganos competentes para ejercer la potestad de ajustar tratados en nombre de sus Estados respectivos, los acuerdos concertados por ellos, o por cualquier otro órgano facultado para actuar en nombre del Estado, que infrinjan las limitaciones constitucionales en vigor, no obligan al Estado interesado. La razón de ello radica en el hecho de que los representantes se han excedido en el ejercicio de sus poderes al estipular los contratos». La consecuencia necesaria de esta sujeción a la Constitución es el control de constitucionalidad de tratados admitido por los internacionalistas. Como nos recuerda Reuter: «Ninguna cuestión se ha debatido más que la inconstitucionalidad formal de los tratados, la cual a veces se conoce con el nombre de "ratificaciones imperfectas». ¿Qué ocurre, por ejemplo, si dos Estados concluyen un tratado y, luego de que sus representantes lo han declarado obligatorio, uno de ellos afirma que no está obligado, debido a que no se han respetado algunos de sus propios requisitos constitucionales?.La validez interna es enteramente distinta e independiente de la validez internacional, como lo sostienen los dualistas? ¿ O un tratado válido a nivel internacional es necesariamente válido en el derecho interno? $\mathrm{O}$ a la inversa, ¿la nulidad interna de un tratado puede lograr que éste sea internacionalmente nulo, en virtud de que el derecho internacional deja la determinación de los procedimientos de celebración de los tratados en manos del derecho constitucional de cada país? Resulta difícil admitir, cuando se canjean los consentimientos, que una de las partes pueda pretender conocer el derecho constitucional de otra parte mejor que los representantes autorizados de esta última; por tanto, de ordinario ambas partes tendrán que aceptar de buena fe la declaración de su contraparte, porque de otro modo no sería posible obtener ninguna seguridad en las relaciones convencionales. Así lo pone de manifiesto la práctica internacional, y el artículo 46 de la Convención de 1969 establece que un Estado no puede alegar en una situación semejante la violación sea manifiesta y afecte a una norma de importancia fundamental de su derecho interno». Luego añade que: «Una violación es manifiesta si resulta objetivamente evidente para cualquier Estado que proceda en la materia conforme a la práctica usual y de buena fe» ${ }^{18}$.

18 Oppenheim, L. M.A.: «Tratado de Derecho Internacional Público» (trad. J. López O. Y J. M. Castro-Rial de la 8. ${ }^{a}$ edición inglesa a cargo de H. Lauterpacht), 2 vol., Edit. Bosch, Barcelona, 1961 Tomo I, vol. II, pp. 477-478. De Paul Reuter. «Introducción al Derecho de los Tratados», ob. cit., pp. 32-33. También Michael Akehurst: «Introducción al Derecho Internacional» (trad. y notas M. Medina O.), Alianza editorial, $1 .^{a}$ edic. 1973, 2. ${ }^{a}$ edic., Madrid, 1982, pp. 161-184. 
En nuestro medio, la extensión del control de constitucionalidad de tratados ha dado origen a un interesante debate que tiene como protagonistas visibles y en las antípodas a los profesores Nogueira Alcalá y Ribera Neumann ${ }^{19}$. Sin pretender terciar en el debate, me parece que afirmado el control de constitucionalidad por el Tribunal Constitucional de tratados internacionales con carácter preventivo y obligatorio, preventivo y facultativo en los n. ${ }^{\circ} 1 \mathrm{y} \mathrm{n} .^{\circ} 3 \mathrm{del}$ artículo 93 de la Constitución, tal extensión del control es parte de una competencia tasada de esta Judicatura Suprema no admitiendo interpretaciones extensivas, analógicas o activistas montadas sobre la "fuerza de ley» y la custodia de la supremacía e integridad de la Constitución, que permitan un control represivo y facultativo por la vía de la acción de inaplicabilidad y la cuestión de inconstitucionalidad del n. ${ }^{\circ} 6$ y n. ${ }^{\circ} 7$ del mismo artículo 93.

Por lo demás, incorporado o recepcionado el tratado internacional al Derecho interno, éste pasa a integrarse al sistema de fuentes con prevalencia, siendo resistente a fuentes de Derecho interno, de suerte que su nulidad, suspensión, terminación o abrogación sólo puede ser perseguida a través de los mecanismos admitidos (como verbigracia denuncia, retiro) por el Derecho Internacional General y Convencional, y en base a las determinaciones constitucionales en la materia que le confieren atribuciones exclusivas al Presidente de la República y limitadamente al Congreso Nacional (artículo 54 n. ${ }^{\circ} 1$ C.P.R.), fiel a un presidencialismo fuertemente anclado en sus poderes exteriores al principio monárquico. Lo contrario importa exponer al Estado a responsabilidad de Derecho Internacional, por infringir caros principios-reglas de ese orden como son pacta sunt servanda y bona fide de los artículos 26 y 27 de la Convención de Viena sobre Derecho de los Tratados de 1969, responsabilidad cuya fuente inmediata es una decisión judicial de una Judicatura Suprema inmune a la responsabilidad. Una cuestión distinta y Constitutione ferenda es la necesidad de un control preventivo y obligatorio para la totalidad de los tratados internacionales, después de su aprobación por el Congreso Nacional.

A fin de cerrar esta excursión en «terra ignota»: la del Derecho Internacional, la doctrina constitucional contemporánea aborda la relación Derecho Internacional-Derecho interno, tratados-Constitución, con cierta independencia de la querella de escuelas (monismo-dualismo, aunque estas sirvan de presupuestos te-

${ }^{19}$ Consultar H. Nogueira Alcalá: «Reforma Constitucional de 2005 y Control de Constitucionalidad de Tratados Internacionales» y de Teodoro Ribera Neumann «Los Tratados Internacionales y su control a posteriori por el Tribunal Constitucional», ambos en «Estudios Constitucionales» n. ${ }^{\circ}$ 1, Año 5, CECOCH, 2007, pp. 59-88 y pp. 89-118. En la misma revista cabe destacar los trabajos de la profesora Ana María García Barzelatto y Miriam Henríquez Viñas. 
óricos y metateóricos), a partir de la necesidad de situar la discusión en el binomio validez y eficacia. El establecimiento de la eficacia de los tratados internacionales como fuente en el Derecho interno, pasa por las determinaciones del derecho estatal y su Constitución, que definen el locus del tratado en el sistema de fuentes; eficacia que en razón de los principios-reglas pacta sunt servanda y bona fide (cuyo origen es el Derecho Internacional General y Convencional) exigen del Estado dotar al tratado de prevalencia, lo que se traduce no en jerarquía sino en aplicación preferente, cuando la estructura y densidad normativa del tratado lo permiten.

Desde esta perspectiva la incorporación o recepción del tratado internacional al Derecho interno, puede operar en el Derecho Comparado en base a técnicas de adaptación diversas: procedimiento automático, procedimiento especial o un procedimiento ordinario, que incluso puede llevar a exigir "transformación»; procedimientos que pueden englobar la totalidad del Derecho Internacional o distinguir entre Derecho Internacional General y Derecho Internacional Convencional, confiriendo un tratamiento especial a tratados internacionales. Por ello el recurso al argumento de autoridad de iuspublicistas europeos o al Derecho Comparado debe poner buen cuidado de las determinaciones constitucionales acerca del Derecho Internacional y de las técnicas de adaptación preceptivas a cada orden jurídico estatal. Un ejemplo de lo advertido es el uso de reglas de recepción y de habilitación en las constituciones europeas para tratados internacionales, que hacen posible la integración y supranacionalidad.

Una investigación que cito a título ejemplar en este campo la hace Antonio La Pérgola en relación al Derecho italiano, haciendo tabula rasa de la dicotomía "adoption-transformation" y por ende de las posiciones monistas o dualistas, ya que es el ordenamiento estatal el que fija los mecanismos para atribuir eficacia al Derecho Internacional en el seno del ordenamiento interno, tratando a ésta cuestión como un problema de eficacia, y no de validez, configurando una fuente atípica en que el reenvío al Derecho Internacional importa abrir la puerta una producción jurídica derivada de primordial importancia que lleva a algunos autores peninsulares a sostener la entidad de normas «yuxtapuestas», en que la fuente atípica no es sólo objeto sino también «criterio» de control de constitucionalidad ${ }^{20}$.

${ }^{20}$ La Pergola, Antonio: "Constitución del Estado y Normas Internacionales» (trad. J.L. Cascajo Castro y J. Rodríguez Zapata Pérez), Edita UNAM, México DF:, 1985, en especial su prólogo que actualiza los términos de una obra escrita en 1961, pp. 7-57. sobre el valor o rango de las normas introducidas por el art. 10 de la Constitución italiana consultar Cap. II, pp. 247-374. 
Finalmente, a modo de cierre un tanto intempestivo, pero necesario, es menester reconducir lo expuesto en estas «Apostillas» a los dos problemas abordados: relación tratado-Constitución y «treaty making power»; sobre los cuales podemos señalar:

a) Independientemente de las posiciones teóricas y metateóricas monistas y dualistas (pluralistas), es toral determinar el locus de los tratados internacionales a partir de la Constitución, entendiendo a ésta como conjunto de reglas de competencia acerca de la producción de normas jurídicas del sistema.

b) Se hace necesario despojar la lectura y hermenéutica del artículo $5 .^{\circ}$ inciso segundo de la Constitución de sus lastres iusnaturalistas y de su horizonte o techo ideológico originario, que nos sitúa en el «reino de la confusión» o torre de Babel, e identificarla como una cláusula de reenvío a tratados de derechos humanos, que no atañe al locus del tratado en el Derecho interno, sino que cualifica una vinculación de los poderes públicos, conformando una garantía institucional genérica de los derechos fundamentales y de los derechos humanos, que impone deberes de respeto y promoción de estos derechos a todos los órganos del Estado.

c) La Constitución establece una regla de incorporación o recepción de tratados internacionales que configura un procedimiento especial (artículos $32 \mathrm{n}^{\circ} 15$ y $54 \mathrm{n} .{ }^{\circ} 1$ ), que con la reforma constitucional reequilibra en parte los poderes del Gobierno y del Congreso Nacional, no superando el anclaje de los poderes exteriores gubernativos, administrativos y legislativos delegados del Presidente de la República en el principio monárquico, manteniéndose el acusado déficit democrático de los tratados internacionales.

d) Los tratados internacionales son una fuente de Derecho Internacional, orden del cual arranca su validez, y una vez incorporados al Derecho interno, su eficacia normativa es prevalente, en la medida que su aplicabilidad preferente guarda congruencia con los principios-reglas de pacta sunt servanda y bona fide, y la resistencia pasiva de los tratados frente a fuentes nacionales, ya que está sustraída a la normación interna unilateral conducente a la modificación, suspensión, abrogación o anulación. Esta prevalencia está conectada a la estructura normativa y densidad normativa del tratado compatible con la autoejecutabilidad de sus normas o cláusulas.

e) El tratado internacional es una fuente que carece de jerarquía normativa en el sistema de fuentes del Derecho interno, posee aplicabilidad, y en tal 
medida goza de «inderogabilidad» (I. de Otto Pardo ${ }^{21}$. De ello arranca el espinoso tema de la «fuerza legal» activa y pasiva de los tratados, en especial frente a ley y de la aplicación de reglas para resolver conflictos de normas.

f) El tratado tiene en la Constitución una reserva de competencia implícita y abierta, de suerte que puede normar cualquier materia de competencia legislativa o reglamentaria, con la sólo exigencia de quórum especial o preceptivo del artículo 66 y el control de constitucionalidad preventivo y obligatorio de sus normas que "versen sobre materias propias...» de ley orgánica constitucional en los términos del n. ${ }^{\circ} 1$ del artículo 93 de la Constitución, y siempre reconociendo en su base la distinción entre tratados solemnes y tratados simplificados. De esta manera, los tratados de derechos humanos son parte del desarrollo infraconstitucional, junto a la legislación, de los derechos fundamentales, y un refuerzo garantístico extraordinariamente valioso.

g) Los tratados internacionales quedan sometidos a control de constitucionalidad por el Tribunal Constitucional preventivo y obligatorio, y preventivo y facultativo del $n .^{\circ} 1$ y n. ${ }^{\circ} 3$ del artículo 93 de la Constitución. Tal control de constitucionalidad podrá extenderse a vicios de inconstitucionalidad material y formal, y no competencial, a menos que la aprobación por el Congreso Nacional no cumpla con el quórum preceptivo, caso en el cual entronca con la inconstitucionalidad formal.

Para concluir, sólo resta hacer presente que el análisis de esta materia debe alejarse de dos peligros teórico-prácticos, a saber: modificar la Constitución o prescindir de ésta por el uso de un «espejo del propio sistema teórico» (La Pergola) por una parte, y divorciar, la Constitución y la relación tratado-Constitución del principio democrático (B. Aláez), que sólo admite que las reglas de competencia tengan su origen en el Poder Constituyente, como ocurre con las reglas de incorporación o recepción de tratados en el Derecho interno, las reglas de habilitación que permiten transferencia o delegación de potestades soberanas o las normas iusfundamentales relativas a derechos y garantías, que por ser lí-

${ }^{21}$ Otto Pardo, Ignacio de: «Derecho Constitucional. Sistema de Fuentes» Edit. Ariel, Barcelona, 1987, pp. 125-126. También de Alberto Pedrieri «El Sistema de Fuentes del Derecho» en libro colectivo «La Constitución Española de 1978. Estudio Sistemático dirigido por los profs. Alberto Pedrieri y Eduardo García de Enterría, Edit. Civitas, 1. ${ }^{a}$ edic. 1980, 2. ${ }^{a}$ edic. 1981, reimpresión, Madrid, 1988, pp. 161-220. Consultar a Antonio Torres del Moral «Principios de Derecho Constitucional Español», Servicio de Publicaciones, Universidad Complutense, 4. ${ }^{a}$ edic., Madrid, 1998, pp. 229-246. 
mites, directrices u orientaciones del poder político, operan como instituciones «contramayoritarias» en una democracia constitucional ${ }^{22}$.

En suma, el locus de tratados de derechos humanos en el sistema de fuentes de nuestro ordenamiento jurídico, debe amoldarse no sólo a la regla de incorporación o recepción prevista en la Constitución, sino a las decisiones fundamentales que ésta adopta acerca del Estado y del orden socio-político, en particular acerca del principio democrático como basal en la arquitectura del cosmos político. Tal principio democrático exige residenciar en el Poder Constituyente (expresión de la soberanía popular) las decisiones acerca de sus reglas de competencia y la producción de normas. Sólo de este modo se puede explicar coherentemente que la Constitución sea fuente de poderes constituidos en una democracia constitucional, y medida-límite de tales poderes. Ello porque como bien observa Pedrieri «...las fuerzas políticas encuentran en la Constitución el punto de encuentro mínimo, de garantías recíprocas y la traducción formal de una Constitución material...».

Por ende, la aproximación teórica a las fuentes desde principios ordenadores (principio de jerarquía normativa, principio de competencia, principio de especialidad de procedimiento, principio de aplicación), tiene implicancias prácticas de primer orden en una democracia constitucional, en particular el toral principio de jerarquía normativa que entronca directamente con el principio democrático, escalonando las normas en un sistema de normas cuya posición esta directamente o indirectamente asociada a la decisión política autodeterminada del pueblo, que tiene como cierre la Potestad Constituyente; implicancias que no habían escapado al ojo agudo de Kelsen y su discípulo Merkl. La afirmación de Kelsen, uniendo igualdad política y libertad como ideales primarios, es preclara: «La democracia es la idea de una forma de Estado o de Sociedad en la que la voluntad colectiva, o más exactamente, el orden social, resulta engendrado por los sujetos a él, esto es, por el pueblo» ${ }^{23}$.

Pretender conferirle seudo-forma y materialidad constitucional a los tratados internacionales de derechos humanos ratificados y vigentes a través de la noción de «bloque de constitucionalidad de derechos», no sólo incurre en yerros capitales anotados como prescindir de la Constitución y los principios de constitucionalidad, e impregnar la lectura-hermenéutica constitucional de

${ }^{22}$ Aláez Corral, Benito: «Comentario a la Sentencia del Tribunal Constitucional Federal Alemán del 12 de octubre de 1993", Revista Española de Derecho Constitucional, n. ${ }^{\circ}$ 45, CEC, 1995, pp. 243-278.

${ }^{23}$ Kelsen, Hans: «Esencia y Valor de la Democracia» (trad. R. Luengo T.-L. Legaz L.) Edit. Labor, Barcelona, 1977, p. 30. 
lastres iusnaturalistas e ideológicos, sino que importa un severo quebranto al principio democrático, ya encorsetado por el fruto del Poder Constituyente: la Constitución y sus instituciones "contramayoritarias», en una democracia constitucional.

\section{Resumen}

El artículo analiza los derechos humanos en la jurisprudencia del Tribunal Constitucional y sus dos épocas; destacando su crítica a la doctrina del bloque de constitucionalidad.

\section{Abstract}

This article analyze the human rights in the jurisprudence of Constitutional Court and two epoch or times, to make stand out critics at the doctrine of constitutional bloc.

\section{Palabras Claves}

Derechos Humanos, Antes, Después en la Jurisprudencia, Bloque de Constitucionalidad

\section{Key words}

Humans Rights, Before, After in the jurisprudence, Constitutional Bloc 